\title{
Early diagenesis driven by widespread meteoric infiltration of a Central European carbonate ramp: A reinterpretation of the Upper Muschelkalk
}

\author{
Arthur Adams and Larryn W. Diamond \\ arthur.adams@geo.unibe.ch,diamond@geo.unibe.ch \\ Rock-Water Interaction, Institute of Geological Sciences, \\ University of Bern, Baltzerstrasse 3, \\ CH-3012 Bern, Switzerland
}

Preprint of publication in Sedimentary Geology, vol. 362, pp. 37-52, 2017

\begin{abstract}
Meteoric diagenesis of carbonate ramps is often difficult to interpret and can commonly be confused with other coinciding diagenetic processes. The Middle Triassic Upper Muschelkalk of Switzerland provides an insightful case in which the effects of several overprinting diagenetic environments, including matrix dolomitization, can be clearly unravelled. Previous studies suggested that diagenesis took place in connate marine waters, with later meteoric waters being invoked to explain recrystallization of dolomite. In this study, diagenetic analyses $(\mathrm{C}-\mathrm{O}$ stable isotope ratios, thin-section point counting, cathodoluminescence and UV-fluorescence microscopy) of calcitic bioclastic samples have revealed that early diagenesis (pre-stylolitization) and the accompanying porosity evolution did not occur exclusively in the presence of marine fluids. Five sequential stages of diagenesis have been identified: marine, shallow burial, mixing-zone, meteoric and dolomitization. Marine diagenesis induced precipitation of bladed and inclusion-rich syntaxial cements that fluoresce strongly under UV-light. Both cements account for a mean 7.5 vol\% reduction in the porosity of bioclastic beds. Shallow burial diagenesis likely induced mouldic porosity and associated fluorescent dog-tooth cementation. Based on light oxygen isotope and elevated strontium isotope ratios, matrix aragonitecalcite neomorphism is interpreted to have occurred in a mixture of marine and meteoric fluids. The combination of shallow burial and mixing-zone processes reduced porosity on average by 4.8 vol\%. Evidence for subsequent meteoric diagenesis is found in abundant dog-tooth and blocky calcite cements that have mean $\delta^{18} \mathrm{O}_{\mathrm{VPDB}}$ of $-9.36 \%$ and no signs of recrystallization. These meteoric
\end{abstract}


cements reduced porosity by a further $13.4 \mathrm{vol} \%$. Percolation of meteoric water through the ramp was driven by hydraulic gradients on an adjacent basement high, which was exposed by a cycle of early Ladinian regressions. Following meteoric diagenesis the Upper Muschelkalk was dolomitized by refluxing brines. This complex history of diagenesis resulted in moderate porosities in dolomitized rocks (up to 20\%), and low porosities $(<5 \%)$ in calcitic bioclastic beds. These results are used to show that the present-day reservoir properties of non-dolomitized carbonate rocks, particularly bioclastic beds, can be largely attributed to early diagenetic processes. Thus, knowledge of the early diagenetic history and its regional controls provides a means to predict reservoir properties over wide areas between and beyond well sites.

\section{Introduction}

During the sea-level highstands of the Mesozoic, eustatic flooding of intracratonic basins led to the development of extensive shallow-water carbonate ramps in Western Europe (Tucker and Wright, 1990). Diagenesis initially took place in the marine realm, but prior to significant burial a number of these platforms were additionally overprinted by diagenetic processes driven by meteoric water, i.e. karstification, dissolution and meteoric cementation (Mutti and Weissert, 1995; Szulc, 2000; Zeeh and Geng, 2001; Tucker and Marshall, 2004). In a given formation, however, distinguishing between marine and meteoric diagenesis is rarely simple. Cement morphologies once thought to be exclusive to meteoric environments have been found in sediments that have never been affected by meteoric fluids (Walker et al., 1990; Melim et al., 1995; Reinhold, 1999). Non-luminescent to bright- to dullluminescent sequences once attributed to meteoric waters are now known to occur in many marine settings (Kaufmann and Wendt, 2000). Dissolution of aragonite particles does not require meteoric fluids undersaturated in aragonite, but can occur spontaneously during shallow burial in exclusively marine pore fluids (Melim et al., 1995; Cherns and Wright, 2000; Melim et al., 2001; Cherns and Wright, 2009). Consequently, combined petrographic, isotopic and geochemical analyses are required to decipher the origin of the waters that induced diagenesis in most ancient carbonate rocks.

The Middle Triassic Upper Muschelkalk carbonate ramp has been the focus of multiple studies on facies distributions (Merki, 1961; Aigner, 1982; Borkhataria et al., 2005; Franz et al., 2013, 2015), reservoir properties (Braun, 2003; Ruf and Aigner, 2004; Palermo et al., 2012) and dolomitization (Schauer and Aigner, 1997; Zeeh and Geng, 2001). However, apart from the latter works specialized on dolomitization, few publications (Bachmann, 1973; Braun, 2003) have examined the early (prestylolitization) diagenesis of the formation as a whole. Early diagenesis of the Upper Muschelkalk involved primarily calcite cementation and matrix dolomitization. Bachmann (1973) attributed the early cements to marine and burial diagenesis in connate marine fluids, although this conclusion was reached without the benefit of stable isotope analyses of the cements or petrographic analyses of their timing relative to matrix dolomitization. Subsequently, Schauer and Aigner (1997) viewed matrix 
dolomitization as an early phenomenon caused by seepage-reflux of dense brines prior to significant burial. The light oxygen isotope values and high ${ }^{87} \mathrm{Sr} /{ }^{86} \mathrm{Sr}$ ratios of the matrix dolomites were then interpreted as evidence for later shallow burial stabilization (Schauer and Aigner, 1997) or possible precipitation or recrystallization in mixed meteoric/marine waters (Zeeh and Geng, 2001). While isotopic data may indicate the influence of meteoric fluids, the source, timing and characteristics of these fluids have not been identified.

The aims of the present study are (i) to fully characterise early diagenesis in the Upper Muschelkalk of northern Switzerland including the timing of matrix dolomitization relative to early cementation; and (ii) to analyse the effects of early diagenesis on the reservoir properties of the nondolomitized bioclastic beds in Switzerland and Germany. By presenting the first petrographic and stable isotope evidence for transformations prior to dolomitization, we demonstrate that early meteoric cementation was indeed the most significant diagenetic process affecting the reservoir properties of the calcitic Upper Muschelkalk. The results of this study are significant for $\mathrm{CO} 2$ sequestration and other gas-storage possibilities in Switzerland, for which the Upper Muschelkalk is regarded as one of the largest potential reservoirs (Chevalier et al., 2010).

\section{Geological setting}

During the Anisian-Ladinian, Switzerland was located at a paleolatitude of approximately $20^{\circ} \mathrm{N}$ in the south-eastern intracontinental Central European Basin (CEB) (Fig. 2.1A) (Stampfli and Borel, 2002). Northern Switzerland (Fig. 2.1B) occupied a region in the Upper Muschelkalk Sea, located tens of kilometres offshore from the Vindelician High. The basin hosted the extensive Upper Muschelkalk epeiric sea with only restricted connections to the Tethys Ocean owing to four tectonically controlled gates and the Vindelician High in the south-east (Ziegler, 1990) (Fig. 2.1A). Carbonate sediments of the Upper Muschelkalk are interpreted to have deposited on an open marine homoclinal ramp separated from a sheltered lagoon by ooid and shell shoals (Aigner, 1982). The ramp accumulated during the peak marine conditions of the overall transgressive-regressive cycle of the Germanic Triassic (Aigner et al., 1998). The Upper Muschelkalk is overlain and underlain by massive evaporitic units that were deposited during low sea-level stands (Fig. 2.2). Upper Muschelkalk thickness increases from $50 \mathrm{~m}$ in eastern Switzerland to $85 \mathrm{~m}$ towards the basin centre in north-central Switzerland (Pietsch et al., 2016).

The climate during the Middle Triassic was warm and humid in the southern CEB (Franz et al., 2015) and favoured powerful monsoonal winter storms (Parrish, 1993). Evidence of regular storm activity is observed in the Upper Muschelkalk in the form of tempestite deposits dispersed in the dominantly calcitic mudstones of the Trochitenkalk (Aigner, 1985), which is the German equivalent to the Swiss Hauptmuschelkalk (Jordan, 2016; Pietsch et al., 2016). Wackestone- packstone tempestites were deposited in the distal- and mid-ramp environments, whereas grainstone ooid and 
shelly shoals protected a coastal lagoon from the influence of storms (Aigner, 1985). The coastal barrier eventually restricted the incursion of marine waters into the lagoon, such that desiccation cracks were formed alongside laminated, lenticular, nodular and chicken-wire sulphates in hypersaline conditions at the top of the Trigonodus Dolomit (Schauer and Aigner, 1997). Following sulphate deposition, a basin-wide erosive surface developed, followed by deposition of the Grenzbonebed and the overlying brackish/terrestrial Lettenkohle unit (Pöppelreiter and Aigner, 2008). Owing to this erosion, the nature of the last beds deposited prior to the Lettenkohle is unknown.

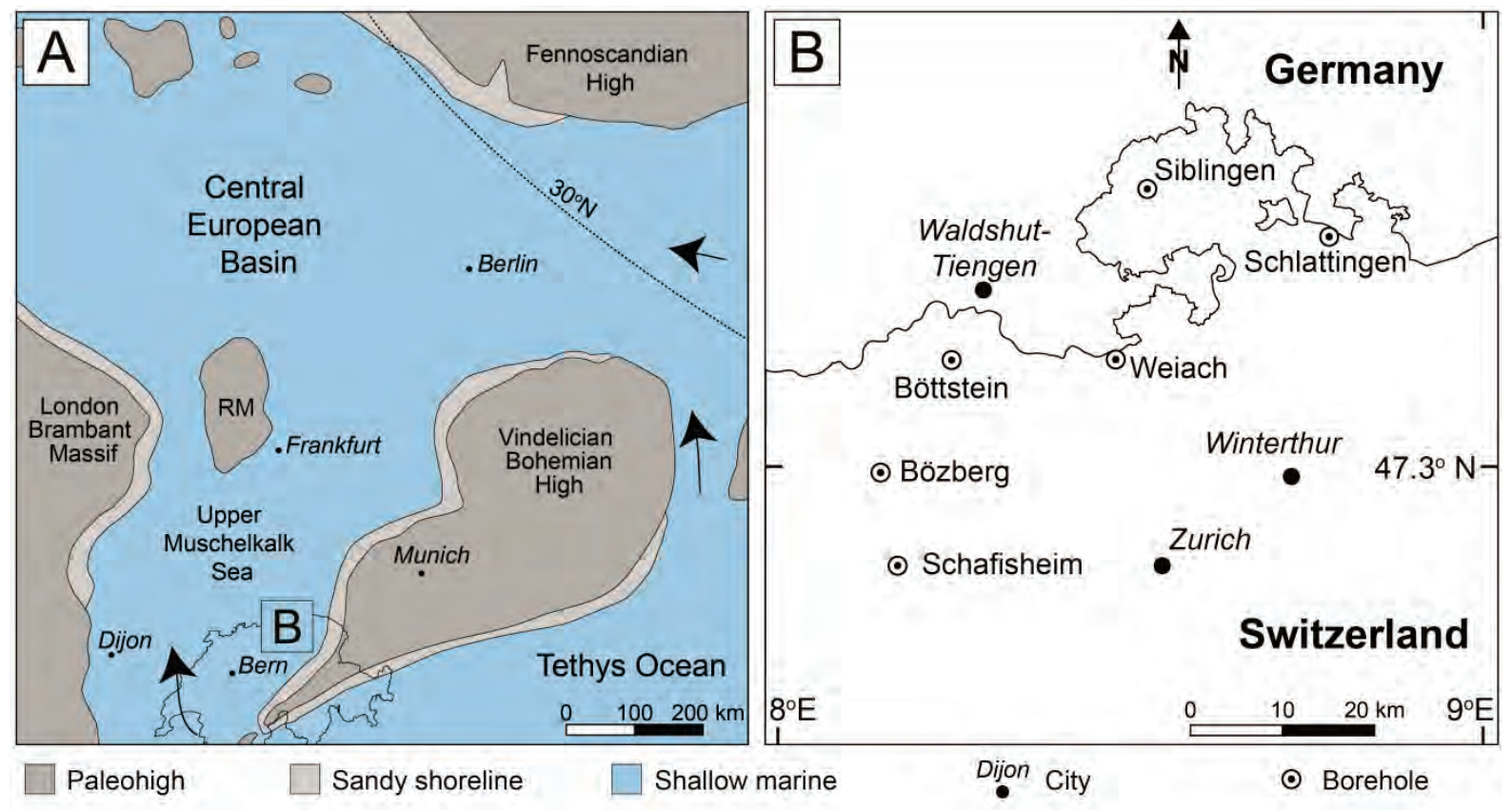

Figure 2.1. (A) Paleogeographic reconstruction of the Central European Basin during the Middle Triassic modified from Ziegler (1990). (B) Location of examined boreholes within northern Switzerland.

The 20 to $30 \mathrm{~m}$ of sediment directly below the Lettenkohle corresponds to the Trigonodus Dolomit, the dolomitized half of the Upper Muschelkalk of Switzerland (Pietsch et al., 2016). The precursors to these dolomites represent the sheltered lagoonal facies of the Upper Muschelkalk carbonate ramp (Schauer and Aigner, 1997) and consist mostly of low-energy mudstones with intercalated bioclastic beds (Merki, 1961; Diamond et al., 2013). Matrix dolomite in the Trigonodus Dolomit is clearly replacive (Merki, 1961) but the identification of its origin is hampered by significant recrystallization that may have occurred due to the influence of meteoric waters (Schauer and Aigner, 1997; Zeeh and Geng, 2001). However, the source of the recrystallizing fluids has not been determined. Korte et al. $(2003,2005)$ suggested that the Upper Muschelkalk Sea received over a quarter of all its waters from freshwater runoff from the Vindelician High. Consistent with this conclusion, the strontium isotope composition of primary anhydrite shows values significantly higher than Middle Triassic seawater (Pearson et al., 1991). Furthermore, at the conclusion of the Upper Muschelkalk deposition, the terrestrial/brackish Lettenkohle environment prograded from the north, 
bringing continental waters far into the basin (Franz et al., 2013). Despite the apparent influx of meteoric fluids during the Middle Triassic, the role of continental waters from the Vindelician High in diagenesis and dolomitization of the Upper Muschelkalk has not yet been understood.

\begin{tabular}{|c|c|c|c|c|c|c|c|}
\hline Epoch & Age & \multicolumn{2}{|c|}{ Disler (1914) } & DSK (2002) & Jordan (2016) & Lithology & $\begin{array}{c}\text { Thickness } \\
\text { in Switzerland (m) }\end{array}$ \\
\hline \multirow{7}{*}{$\begin{array}{l}\frac{0}{0} \\
0 \\
0 \\
\frac{\pi}{2} \\
\frac{0}{0} \\
\frac{0}{0} \\
\frac{0}{2}\end{array}$} & \multirow{7}{*}{ 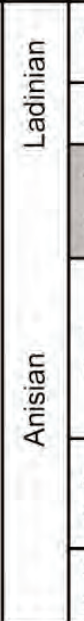 } & Gipskeuper & \begin{tabular}{|l|} 
Middle \\
Keuper
\end{tabular} & Grabfeld Fm. & Bänkerjoch Formation & $\hat{\hat{\hat{n} \hat{\wedge} \hat{\hat{n}} \hat{n}}}$ & $>70$ \\
\hline & & Lettenkohle & Low. Keuper & Erfurt Fm. & \multirow{4}{*}{$\begin{array}{l}\text { Schinznach } \\
\text { Formation }\end{array}$} & $\overline{1}$ & $\sim 10$ \\
\hline & & $\begin{array}{l}\text { Trigonodus- } \\
\text { dolomit }\end{array}$ & \multirow{3}{*}{$\begin{array}{l}\text { Upper } \\
\text { Muschelkalk }\end{array}$} & $\begin{array}{l}\text { Rottweil } \\
\text { Formation }\end{array}$ & & $1 /$ & $\sim 28$ \\
\hline & & \multirow{2}{*}{$\begin{array}{l}\text { Haupt- } \\
\text { muschelkalk }\end{array}$} & & $\begin{array}{l}\text { Meißner } \\
\text { Formation }\end{array}$ & & & \multirow[t]{2}{*}{$\sim 40$} \\
\hline & & & & $\begin{array}{l}\text { Trochitenkalk } \\
\text { Formation }\end{array}$ & & & \\
\hline & & $\begin{array}{l}\text { Anhydrit- } \\
\text { dolomit }\end{array}$ & \multirow{2}{*}{$\begin{array}{c}\text { Middle } \\
\text { Muschelkalk }\end{array}$} & $\begin{array}{l}\text { Diemel } \\
\text { Formation }\end{array}$ & \multirow{2}{*}{ Zelingen Formation } & 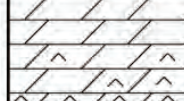 & $\sim 15$ \\
\hline & & $\begin{array}{l}\text { Sulfat- } \\
\text { schichten }\end{array}$ & & $\begin{array}{l}\text { Heilbronn } \\
\text { Formation }\end{array}$ & & 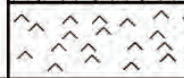 & $\sim 40$ \\
\hline 87 & & & \begin{tabular}{|l|l|}
1 & 11 \\
\end{tabular} & Limestone & \multicolumn{2}{|l|}{ Marl } & $\hat{\wedge}$ Sulphate \\
\hline
\end{tabular}

Figure 2.2. Stratigraphic divisions of the Upper Muschelkalk and surrounding units according to various authors. DSK denotes Deutsche Stratigraphische Kommission (2002). Note the erosional contact between the Trigonodus Dolomit and Lettenkohle. The classification of Disler (1914) is used throughout this study.

\section{Methods and materials}

Drill core samples were collected from six wells drilled in northeastern Switzerland by Nagra (National Cooperative for the Disposal of Radioactive Waste) and SBB (Swiss Federal Railways) (Fig. 2.1B). One hundred and thirteen thin sections from bioclastic and dolomitized beds were selected. Thin sections were analysed at the University of Bern by several methods: conventional, plane-polarized transmitted light microscopy (PPL); UV-epifluorescence microscopy (UV-F); laser Raman spectroscopy using a Horiba Jobin-Yvon LabRam HR-800 confocal instrument coupled to a transmitted-light microscope with a $100 \times$ objective lens; and hot-cathodoluminescence microscopy (CL) using a $20 \mathrm{kV}$ beam as described by Ramseyer et al. (1989).

Calcite cements for stable isotope analysis were identified from thin sections and sampled from their corresponding rock slabs using a micro-drill and the resulting powder was reacted with anhydrous phosphoric acid at $70{ }^{\circ} \mathrm{C}$. Since the calcite matrix of the Upper Muschelkalk often contains small amounts of dolomite, the selective acid-extraction method of Al-Aasm et al. (1990) was performed at $25{ }^{\circ} \mathrm{C}$ on all micro-drilled matrix powders. This method takes advantage of the different reaction rates of calcite and dolomite with phosphoric acid at low temperatures, by which the first $\mathrm{CO}_{2}$ yielded from the reaction predominately results from the calcite component in a mixed dolomite/calcite sample. Aliquots were analysed for $\delta^{18} \mathrm{O}$ and $\delta^{13} \mathrm{C}$ in a Finnigan Delta V Advantage mass spectrometer. The isotope ratios of calcite were corrected by a Carrara marble internal standard. 
The area fractions of pores and various cements were calculated by point counting (500 points per slide at $200 \mu \mathrm{m}$ spacing) on 25 thin sections from three boreholes. The samples show no preferred orientations of pores or cements and so the area fractions are considered equal to volume fractions. To enable point counting, over $25 \mathrm{~mm}^{2}$ of each thin section was photographed using a $10 \times$ objective under UV-F and PPL illumination. During point counting, the mineralogy, various cements, primary porosity, secondary porosity and micritic envelopes were distinguished. Non-fluorescent cements were indistinguishable under PPL or UV-F and were therefore grouped as CL-luminescent cements.

\section{Results}

\subsection{Description of cement stages}

The various cathodoluminescent and UV-fluorescent cements have been divided into temporal stages, which are further separated into individual zones as done by Emery and Marshall (1989). Hereafter we refer to cathode-activated emission simply as "luminescence" and UV activated emission simply as "fluorescence". An individual zone is thus characterized by a single dominant luminescent/fluorescent colour, which may contain thin subzones of other colours. An individual stage may be characterized by multiple zones or a single dominant band. Four CL stages were identified in each borehole.

\subsubsection{Luminescent stage 1(LS $)$}

Luminescent stage 1 is most representative of the microspar matrix and of bladed, inclusion-rich syntaxial and fluorescent dog-tooth cements. Under CL it has a dull, mottled texture with nonluminescent patches that show bright fluorescence (Fig. 2.3A,B). Often $\mathrm{LS}_{1}$ is replaced or overlain by $\mathrm{LS}_{2}$ and can be best identified by fluorescence microscopy, since later luminescent stages are nonfluorescent.

\subsubsection{Luminescent stage $2\left(L S_{2}\right)$}

Luminescent stage 2 is observed in all facies. It consists of two to ten zones of alternating bright and dull luminescence. Zonation patterns may vary with depth within a borehole. The youngest zones are observed coating the broken edges of shells that have undergone mechanical compaction. Only the thickest zones are correlatable within boreholes. The general pattern is from dull to bright luminescence with decreasing age (Fig. 2.3A,C). However, luminescence never reaches the same intensity as in $\mathrm{LS}_{3}$. Outer zones are occasionally corroded and directly overlain by $\mathrm{LS}_{4}$. This stage, however, is rarely observed uncoupled from $\mathrm{LS}_{3}$. It is associated with dog-tooth and inclusion-free syntaxial cements. The entire stage is non-fluorescent, except for the cases where $\mathrm{LS}_{1}$ has been replaced. 

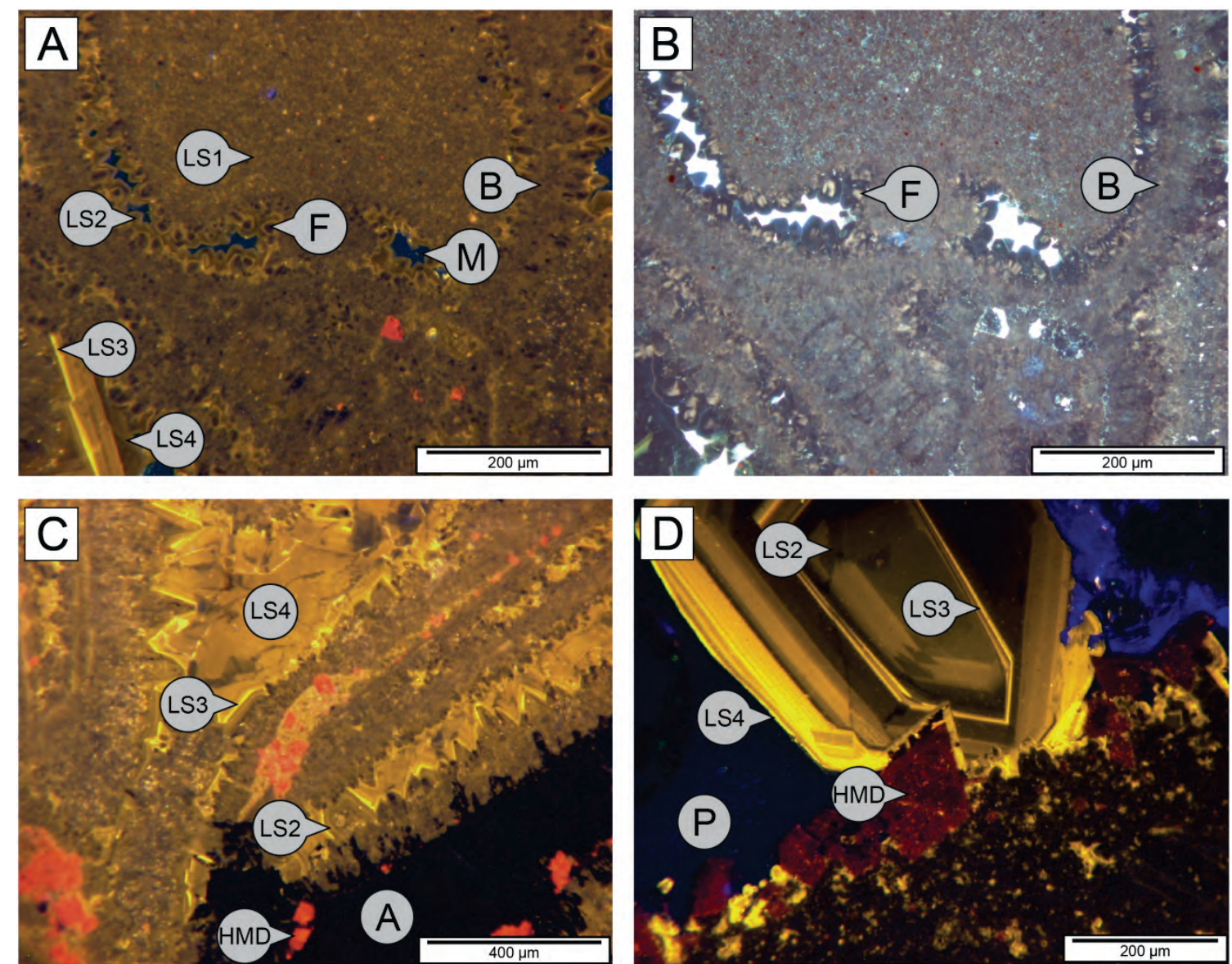

Figure 2.3. Photomicrographs of luminescent cements. Abbreviations: A - anhydrite, B - bladed cement, D - matrix dolomite, F fluorescent cement, HMD - Hauptmuschelkalk dolomite, IFS - inclusion-free syntaxial cement, IRS - inclusion-rich syntaxial cement, L undifferentiated luminescent cement, $\mathrm{LS}_{1-4}$ - luminescent cement stages, $\mathrm{M}$ - mouldic pores, $\mathrm{P}$ - open pore, $\mathrm{S}-$ silicification. A) Cathodoluminescence image of a mollusc mould. Moulds are filled with $\mathrm{LS}_{2}$ cements, whereas the exterior of moulds are covered in bladed cements. Note the non-luminescence of the fluorescent dog-tooth cement. (Bözberg $101.60 \mathrm{~m}$ ). B) Image A under UV-fluorescence. Note the strong fluorescence in the non-luminescent zone of the fluorescent dog-tooth cement. C) Cathodoluminescence image of HMD replacing poikilotopic anhydrite (Schafisheim $1256.09 \mathrm{~m}$ ). D) Hauptmuschelkalk dolomites replace all stages of luminescent cements in a western borehole (Böttstein $175.78 \mathrm{~m}$ ).

\subsubsection{Luminescent stage $3\left(L S_{3}\right)$}

Luminescent stage 3 is a distinctive marker between $\mathrm{LS}_{2}$ and $\mathrm{LS}_{4}$. It consists of a thin, extremely luminescent zone (Fig. 2.3A,C,D). No changes in the thickness of the zone or any subzones have been observed. No fluorescence has been observed. This stage, like $\mathrm{LS}_{2}$, is common to dog-tooth and inclusion-free syntaxial cements.

\subsubsection{Luminescent stage $4\left(L S_{4}\right)$}

Luminescent stage 4 is one of the most abundant of all stages and is characterized by a series of moderately thick zones, up to hundreds of micrometres in thickness (Fig. 2.3D). Numerous subzones may be observed with the overall luminescence typically decreasing towards pores. The luminescent pattern can be complex and irregular. No fluorescence is observed. This stage coats inclusion-free 
syntaxial cements, dog-tooth cements and forms the basis of blocky calcite cement. This cement overgrows all stages of luminescent cements and it often coats pore walls.

\subsection{Petrographic descriptions of diagenetic features}

Diagenetic features have been identified by petrographic examinations under PPL, CL and UV-F illumination. Unless otherwise indicated, all the diagenetic features described in the following section are from non-dolomitized facies. No regional changes in diagenetic relationships have been identified across Switzerland, apart from the number of individual CL zones. Any events that postdate stylolites, which cut all the described features, are not considered in this study.

\subsubsection{Pyritization}

Pyrite is present as individual crystals $(<5 \mu \mathrm{m}$ in diameter) and as clusters of framboidal crystals (10 $40 \mu \mathrm{m}$ in diameter) scattered throughout the Upper Muschelkalk matrix. Micritic envelopes and cements are devoid of pyrites. In the dolomite matrix of the Trigonodus Dolomit, some pyritized allochems remain as ghost structures.

\subsubsection{Micritization}

Micritic envelopes (20-40 $\mu \mathrm{m}$ thick) characterized by $\mathrm{LS}_{1}$ surround bivalves, gastropods, peloids and ooids. Due to differences in fossil distributions, the amount of micritization is stratigraphically variable and it appears more frequently in packstone-grainstone beds near the limestone-dolomite transition at the base of the Trigonodus Dolomit due to their higher content of molluscs. Micritization is generally not observable in dolomitized sections, although some ooids appear to show dolomitized micritic rims.

\subsubsection{Isopachous bladed cement}

Isopachous bladed cement is the first generation of cement overlying the exterior of micritized and non-micritized allochems. Under CL and UV-F, bladed cement exhibits $\mathrm{LS}_{1}$ features (Fig. 2.4A,B). Individual crystals are inclusion-rich, reach $120 \mu \mathrm{m}$ in length, and show blunted terminations. Bladed cements are more common in packstone- grainstone facies but are found in all examined facies.

\subsubsection{Inclusion-rich syntaxial cement}

This syntaxial cement occurs earlier than inclusion-free syntaxial cement. It exclusively encloses echinoderms and can reach over $200 \mu \mathrm{m}$ in thickness. Abundant, brightly fluorescing microscopic inclusions distinguish this cement from the later inclusion-free cement (Fig. 2.4C). Inclusions occasionally appear to radiate from the crinoid, mimicking an acicular/bladed texture. Syntaxial cements are often coated by dogtooth cements and inclusion-free syntaxial cement. Under UV-light it 

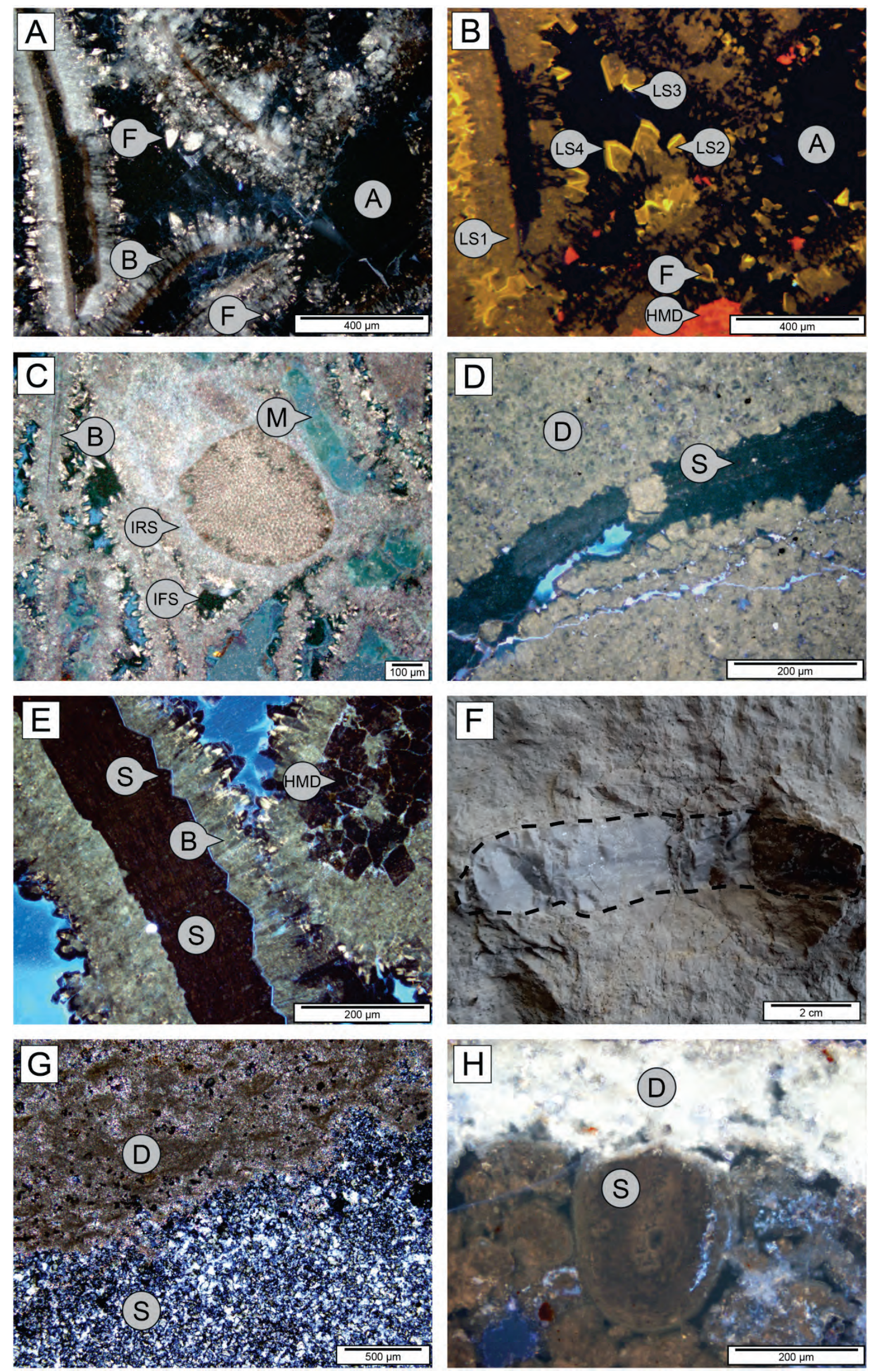
Figure 2.4. Photomicrographs of early diagenetic processes. Same abbreviations as Fig. 2.3. A) Poikilotopic anhydrite replacing most diagenetic features under UV-fluorescence. Note the strong fluorescence of the fluorescent dog-tooth cement at the base of the image. B) Image A under cathodoluminescence. Late stage $\mathrm{LS}_{4}$ shows dissolution rims in contact with anhydrite. Hauptmuschelkalk dolomites overgrow anhydrites at the bottom of the image. The same fluorescent cement at the base of the image now shows a patch of a dark nonluminescent zone. Blocky cement grows in the mouldic space below the $\mathrm{LS}_{2}$ icon. C) UV-fluorescence image of a crinoid ossicle cemented by IRS followed by IFS. Mouldic pores associated with HMD are visible on the right and bottom of the image (Bözberg $128.30 \mathrm{~m}$ ). D) Under UV-fluorescence relict structures are clearly visible in silicified brachiopods, even in dolomitized sections (Schlattingen $1134.94 \mathrm{~m}$ ). E) Silicification under UV-fluorescence. The silicification icon points to sharp tongues of silica replacing bladed cements. Bladed cements grow perpendicular to the brachiopod, rather than to silicified faces (Böttstein $154.80 \mathrm{~m}$ ). F) Typical chert nodule shape in dolomite from Lauwil, Switzerland. G) Under cross-polarized light relict silicified structures are impossible to distinguish. Silicification also creates a sharp boundary with the surrounding matrix dolomites (Weiach $822.11 \mathrm{~m}$ ). H) UV-fluorescence image of the edge of a chert nodule. The upper dolomitized fraction shows the fabric-destructive nature of matrix dolomitization, while the silicification has perfectly preserved the original textures (Weiach $822.11 \mathrm{~m}$ ).

has a bright fluorescence like the matrix and coated crinoids (Fig. 2.4C). Inclusion-rich syntaxial cement is characterized by $\mathrm{LS}_{1}$ and is often difficult to distinguish from the microspar matrix.

\subsubsection{Silicification}

Two types of silicification have been identified; silicification of brachiopods and echinoderms, and $\mathrm{cm}-\mathrm{dm}$ sized nodular cherts. Fossil silicification in the form of chalcedony or micro-quartz is often mimetic and preserves the original fabric along with lineations of pyrite. Well preserved silicified brachiopods are observed in the Trigonodus matrix dolomite (Fig. 2.4D). Carbonate cement is rarely replaced, although small tongues of silica may "intrude" the base of bladed cements (Fig. 2.4E). Small, 1 to $10 \mu \mathrm{m}$ euhedral carbonate crystallites in optical continuity with the host echinoderms are apparent within many silicified regions. Raman spectroscopy revealed that the crystallites are microdolomites.

Chert nodules are often isolated from one another (Fig. 2.4F), but are mostly found at the same stratigraphic height a few meters below the top of the Trigonodus Dolomit. Chicken-wire anhydrite nodules and massive anhydrites at the top of the Trigonodus Dolomit are chertified in multiple boreholes in northern Switzerland. The chert nodules are composed of microquartz, which exhibits sharp boundaries against the surrounding dolomite (Fig. 2.4G). Under UV-light the former calcitic textures are distinctly preserved, whereas in the dolomitized rock they are obliterated (Fig. $2.4 \mathrm{H})$. Non-luminescent mamelon silica cements, reaching over $100 \mu \mathrm{m}$ in thickness, are the only diagenetic components preserved within chert nodules. These cements are not present outside of chert nodules.

\subsubsection{Microspar matrix and mouldic porosity}

The matrix is composed of a low magnesium calcite (LMC) microspar. Average crystal size of the microspar varies between 5 and $30 \mu \mathrm{m}$ in diameter. Microspar is characterized by $\mathrm{LS}_{1}$ and is moderately fluorescent.

Mouldic dissolution of molluscs (bivalves and gastropods) occurred in all facies. Mouldic pores have been filled by dog-tooth and blocky cements but lack bladed cements (Fig. 2.3A,B). Mouldic pores are also present in the Trigonodus Dolomit, where they are occluded by dolomite cements. 


\subsubsection{Fluorescent dog-tooth cement}

This dog-tooth cement lines mouldic pores and the tips of bladed cements (Figs. 2.3B and 2.4A). It is the most abundant cement of the Hauptmuschelkalk. Crystals are often $<10 \mu \mathrm{m}$ in length but may reach up to $30 \mu \mathrm{m}$. It is inclusion-poor but considerably more fluorescent than bladed cements. It may coat the edges of previously cemented broken bioclasts. Fluorescent dog-tooth cement is the youngest stage that displays $\mathrm{LS}_{1}$ features. It is found in all facies, boreholes and depths and it often forms the nucleation surfaces for dog-tooth cement II.

\subsubsection{Dog-tooth cement II}

This inclusion-poor cement occurs within mouldic pores and overgrows bladed cements throughout the Hauptmuschelkalk (Fig. 2.4A,B). Occasionally, fine crystals have grown into fractures created by mechanical compaction. Individual crystals are up to $100 \mu \mathrm{m}$ in length with scalenohedral morphologies. Dog-tooth cement II is the first cement to display three luminescent stages from $\mathrm{LS}_{2}-$ $\mathrm{LS}_{4}$. Dog-tooth II and inclusion-free syntaxial cements show the same luminescent stages in the same boreholes.

\subsubsection{Inclusions-free syntaxial cement}

These cements are most abundant in echinoid-rich facies. They envelop bladed and dog-tooth cements and the edges of uncemented broken shells (Fig. 2.5A). Inclusion-free syntaxial cement is characterized by $\mathrm{LS}_{2}-\mathrm{LS}_{4}$. Dolomitized inclusion-free syntaxial cements are present in the Trigonodus Dolomit (Fig. 2.5B,C).

\subsubsection{Blocky cement}

Blocky cement is one of the most abundant cements in the Upper Muschelkalk. It occurs principally in bioclast-rich beds, and typically occludes all mouldic pore spaces. Crystal sizes slightly increase towards the centres of pores and range in the hundreds of micrometres (Fig. 2.3D). No inclusions have been observed. Blocky cement typically displays only $\mathrm{LS}_{4}$ features. Individual zones are not correlatable from eastern to western Switzerland.

It is clear that blocky cement is not a neomorphic spar. This is evident by (1) the lack of relic features within the cements (Fig. 2.5A), (2) the crystal size increase towards the interior of the pores, which is not a characteristic of neomorphic spar, (3) the occurrence of the same cement morphologies and zonations within and coating mouldic pores (Fig. 2.4B) and (4) the occurrence of earlier cements within mouldic pores implying dissolution prior to blocky cement precipitation (Figs. 2.3A and 2.4B). 

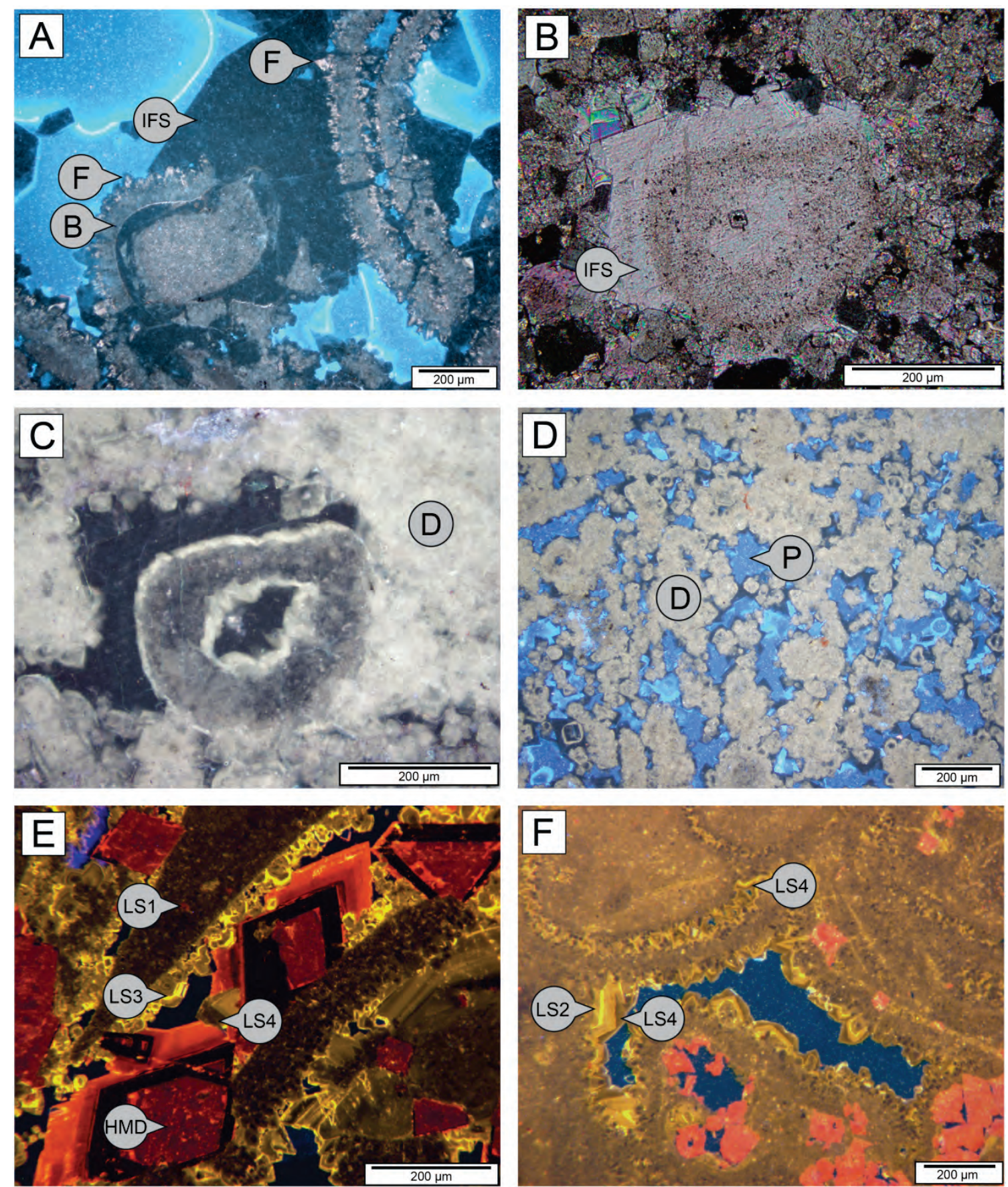

Figure 2.5. Photomicrographs of dolomites and early diagenetic processes. Same abbreviations as Fig. 2.3. A) UV-fluorescence image of IFS surrounding a detached rim of bladed cement. Cement shows no fluorescent inclusions surrounding detached cement rim (Schlattingen $1154.74 \mathrm{~m})$. B) Cross-polarized image of a dolomitized crinoid and surrounding cement. The epitaxial cementation is uncommon for dolomitized sections, and indicates a replacement of pre-existing IFS (Lindau $2262.11 \mathrm{~m}$ ). C) Image B under UV-fluorescence. D) Trigonodus matrix dolomite under UV-fluorescence. Dolomite cements are visible as non-fluorescent crystals growing into pore space (blue) (Schlattingen, 1127.79). E) Hauptmuschelkalk dolomites overgrow all stages of luminescent cements in an eastern borehole (Schlattingen $1154.74 \mathrm{~m}$ ). F) Cathodoluminescence image of paragenetic relationships between early cements. Blocky cement (LS $\left.\mathrm{L}_{4}\right)$ grows within interparticle spaces around $\mathrm{LS}_{2}$ as well as within mouldic pores above. Note the additional vugs devoid of any cements but occluded by HMD at the base of the image (Bözberg $128.30 \mathrm{~m}$ ). 


\subsubsection{Matrix dolomite}

Matrix dolomite is the primary component of the Trigonodus Dolomit. The unit is fully dolomitized in a matrix-replacive and fabric destructive manner (Fig. 2.5C,D), with no calcitic bioclasts present throughout its entire thickness. The matrix dolomite crystals are euhedral- anhedral and fine-grained (2-40 $\mu \mathrm{m}$ diameter) with inclusion-rich cores showing dull-yellow fluorescence under UV-light and occasionally with inclusion-poor, non-fluorescent rims. Cathodoluminescence reveals a mottled texture with multiple generations of dolomite. Comparable dolomites to the Trigonodus matrix dolomites are not present within the Hauptmuschelkalk.

\subsubsection{Anhydrite cement and replacement}

Three varieties of diagenetic anhydrites occur in the westernmost boreholes of Schafisheim and Pfaffnau; (1) poikilotopic anhydrite, (2) replacive anhydrite and (3) replacive anhydrite nodules. Vugs, resulting from the later dissolution of replacive anhydrite nodules, are also prominent features in the Trigonodus Dolomit of more eastern boreholes (Diamond et al., 2013). All varieties occur in non-dolomitized and dolomitized rocks. However, the abundance of anhydrite decreases with depth and it is therefore rare in the Hauptmuschelkalk. All anhydrite appears to postdate all pre-stylolite diagenetic features including blocky cement, with the exception of Hauptmuschelkalk dolomites and dedolomitization (Fig. 2.4A,B). Both matrix dolomites and dolomite cements are enclosed by poikilotopic anhydrite and large anhydrite nodules.

\subsubsection{Hauptmuschelkalk dolomite and dissolution}

Hauptmuschelkalk dolomite (HMD) is a fine-medium crystalline $(60-250 \mu \mathrm{m})$, sucrosic, planar-e dolomite that occurs in the Hauptmuschelkalk and the base of the Trigonodus Dolomit. Under UV light, HMD is non-fluorescent (Fig. 2.4E). Three intracrystalline zones are identified in eastern Switzerland based on CL features: (1) a dull luminescent zone, (2) a completely non-luminescent zone and (3) a brightly luminescing zone (Fig. 2.5E). In central Switzerland two intracrystalline zones are observed: (1) a dull luminescent core and (2) and thin bright luminescent zone with a corroded exterior (Fig. 2.5F). All zones show sharp boundaries with one another. Hauptmuschelkalk dolomite beds are cut by stylolites.

Some bioclastic beds contain non-fabric selective vuggy porosity. Vugs are often small and rarely reach diameters $>1 \mathrm{~mm}$. No cement phases precipitate within these vugs; however, HMD are commonly found growing within these pores and are the only associated diagenetic features with these vugs (Fig. 2.5F). These vugs are exclusive to the Hauptmuschelkalk.

\subsubsection{Dedolomitization}

Dedolomitization affects matrix dolomites and HMD. The most prominent dedolomitization occurred a few meters directly below the base of the Trigonodus Dolomit. This interval is characterized by 
decimetre-thick alternations of HMD and calcitic beds. Dissolution often began from the outside of the crystal and progressed inwards affecting all CL zones. Dedolomite shows no differing CL or UV characteristics from the surrounding calcitic matrix.

\subsection{Point counting}

Point counting of 25 samples show that cements make up on average $35 \mathrm{vol} \%$ of bioclastic beds (Table 2.1). The average vol\% occupied by each cement phase is calculated by multiplying the average of all total cement volumes (Table 2.1) (34.59) by the average of the sum of the cement fraction divided by 100 e.g. $34.59 \times 15.90$ (average bladed cement fraction) $/ 100=5.50 \mathrm{vol} \%$ porosity is occluded by bladed cements on average. Cement volume varies from $8 \%$ to nearly $70 \%$ depending on, respectively, whether the bed was a wackestone or grainstone. The most abundant cements on average are luminescent cements, including dog-tooth II, inclusion-free syntaxial cements and blocky cements, which comprise on average $39 \mathrm{vol} \%$ of all cements. They are closely followed by fluorescent dog-tooth cement, which constitutes $38 \mathrm{vol} \%$ of all cements. Bladed and inclusion-rich cements account for less than a quarter of all cement types. Anhydrite cement is only present in the Schafisheim borehole, but depending on the thin section it can vary from 0 to $46 \mathrm{vol} \%$ of all cements. No depth trends were observed and all cements are present at all stratigraphic positions.

Present-day primary porosities are low, ranging from $0 \%$ to $17 \%$ based on point counting, with an average of $4 \%$. Porosities determined by digital image analysis correlate well with those determined by helium pycnometry (Table 2.1). The estimated porosity prior to cementation, which includes present-day primary porosity, is on average $27 \%$. For grainstones and packstones this value refers to the maximum porosity. For wackestones it corresponds to the minimum porosity due to their greater mud contents, which are now compacted. Hauptmuschelkalk dolomite contents are on average $8 \mathrm{vol} \%$ in bioclastic beds and display a large range from 0 to $58 \%$ of the bed volume. This dolomite is almost entirely replacive and does not reduce porosity in bioclastic beds by $>1 \%$. 
Table 2.1. Volume fractions of pores and cements in Hauptmuschelkalk bioclastic beds, determined by point counting.

\begin{tabular}{|c|c|c|c|c|c|c|c|c|c|c|c|c|c|}
\hline \multirow[t]{2}{*}{ Borehole } & \multirow[t]{2}{*}{$\begin{array}{l}\text { Dunham } \\
\text { classification }\end{array}$} & \multirow[t]{2}{*}{ Depth (m) } & \multirow{2}{*}{$\begin{array}{l}\text { Current } \\
\text { porosity } \\
\phi\left({\text { vol } \%)^{\mathrm{a}}}^{2}\right.\end{array}$} & \multirow{2}{*}{$\begin{array}{l}\text { Porosity } \\
\text { prior to } \\
\text { cements } \\
\phi\left(\mathrm{vol}^{\mathrm{b}}\right)^{\mathrm{b}}\end{array}$} & \multirow[t]{2}{*}{$\begin{array}{l}\text { Dolomite } \\
\text { (vol\%) }\end{array}$} & \multirow{2}{*}{$\begin{array}{l}\text { Total } \\
\text { cement } \\
\text { (vol\%) }\end{array}$} & \multicolumn{5}{|c|}{$\begin{array}{l}\text { Fraction of specified cement with respect to total cements } \\
\text { (vol\%) }\end{array}$} & \multirow{2}{*}{$\begin{array}{l}\text { Mouldic } \\
\text { pores } \\
\text { (vol\%) }\end{array}$} & \multirow{2}{*}{$\begin{array}{l}\text { Dolomite } \\
\text { dissolutiol } \\
(\text { vol\%) })^{c}\end{array}$} \\
\hline & & & & & & & Bladed & $\begin{array}{l}\text { Fluorescent } \\
\text { Dog-tooth }\end{array}$ & IRS & $\begin{array}{l}\text { Luminescent } \\
\text { cements }\end{array}$ & $\begin{array}{l}\text { Anhydrite } \\
\text { cement }\end{array}$ & & \\
\hline Schafisheim & Wackestone & 1272.50 & 0.2 & 47.0 & 2.0 & 50.6 & 9.1 & 30.4 & 0.0 & 14.2 & 46.2 & 3.8 & 0.0 \\
\hline Schafisheim & Wackestone & 1267.71 & 0.0 & 7.6 & 0.0 & 24.6 & 5.7 & 45.5 & 0.0 & 48.8 & 0.0 & 17.0 & 0.0 \\
\hline Schafisheim & Wackestone & 1262.30 & 1.6 & 3.8 & 22.8 & 11.4 & 21.1 & 36.8 & 0.0 & 42.1 & 0.0 & 7.6 & 1.6 \\
\hline Schlattingen & Wackestone & 1166.75 & 0.0 & 5.8 & 8.6 & 7.8 & 0.0 & 20.5 & 2.6 & 76.9 & 0.0 & 2.0 & 0.0 \\
\hline Schlattingen & Wackestone & 1160.76 & 1.2 & 24.2 & 4.4 & 27.0 & 17.8 & 9.6 & 24.4 & 48.1 & 0.0 & 3.0 & 0.0 \\
\hline Schlattingen & Wackestone & 1155.63 & 2.0 & 11.2 & 8.2 & 16.4 & 13.4 & 45.1 & 0.0 & 41.5 & 0.0 & 5.6 & 0.0 \\
\hline Bözberg & Wackestone & 123.76 & 4.4 & 9.2 & 0.0 & 26.4 & 9.1 & 30.3 & 2.3 & 58.3 & 0.0 & 17.2 & 0.0 \\
\hline Bözberg & Wackestone & 121.70 & 0.0 & 9.7 & 0.4 & 22.7 & 7.8 & 44.0 & 0.9 & 47.4 & 0.0 & 13.0 & 0.0 \\
\hline Bözberg & Wackestone & 114.75 & 16.0 & 23.4 & 2.8 & 25.4 & 19.7 & 16.5 & 1.6 & 62.2 & 0.0 & 4.8 & 0.0 \\
\hline Average & & & 2.8 & 15.8 & 5.5 & 23.6 & 11.5 & 31.0 & 3.5 & 48.8 & 5.1 & 8.2 & 0.2 \\
\hline Schafisheim & Packstone & 1269.71 & $0.0(0.8)$ & 17.0 & 3.2 & 26.6 & 5.3 & 60.9 & 18.8 & 15.0 & 0.0 & 9.6 & 0.0 \\
\hline Schafisheim & Packstone & 1265.24 & 0.0 & 36.8 & 4.4 & 41.4 & 21.3 & 38.6 & 4.8 & 35.3 & 0.0 & 4.6 & 0.0 \\
\hline Schafisheim & Packstone & 1264.76 & $0.2(0.6)$ & 30.2 & 3.0 & 38.6 & 8.8 & 25.9 & 6.7 & 58.5 & 0.0 & 8.6 & 0.0 \\
\hline Schlattingen & Packstone & 1158.69 & 0.0 & 25.0 & 58.2 & 41.2 & 7.3 & 44.7 & 5.8 & 42.2 & 0.0 & 16.2 & 0.0 \\
\hline Schlattingen & Packstone & 1147.95 & 1.8 & 23.0 & 7.4 & 36.0 & 10.6 & 58.3 & 6.7 & 24.4 & 0.0 & 13.2 & 0.0 \\
\hline Bözberg & Packstone & 128.30 & 10.3 & 41.8 & 0.0 & 41.0 & 24.5 & 15.9 & 6.3 & 53.4 & 0.0 & 0.8 & 8.8 \\
\hline Bözberg & Packstone & 119.30 & 1.4 & 52.0 & 1.0 & 54.8 & 11.3 & 37.6 & 10.2 & 40.9 & 0.0 & 4.2 & 0.0 \\
\hline Bözberg & Packstone & 112.84 & 0.0 & 40.6 & 2.0 & 48.4 & 9.1 & 36.4 & 2.9 & 51.7 & 0.0 & 7.8 & 0.0 \\
\hline Bözberg & Packstone & 107.33 & 2.0 & 11.4 & 4.2 & 25.0 & 10.4 & 41.6 & 13.6 & 34.4 & 0.0 & 13.6 & 0.0 \\
\hline Bözberg & Packstone & 106.39 & 12.6 & 32.6 & 2.0 & 32.0 & 21.3 & 51.9 & 0.0 & 26.9 & 0.0 & 1.6 & 0.0 \\
\hline Average & & & 2.8 & 31.0 & 8.5 & 38.5 & 13.0 & 41.2 & 7.6 & 38.3 & 0.0 & 8.0 & 0.9 \\
\hline Schafisheim & Grainstone & 1256.09 & 0.0 & 56.8 & 3.0 & 68.4 & 33.0 & 33.9 & 1.5 & 29.8 & 1.8 & 11.6 & 0.0 \\
\hline Schlattingen & Grainstone & 1154.74 & $8.2(6.9)$ & 36.4 & 8.6 & 41.4 & 40.6 & 26.6 & 0.0 & 32.9 & 0.0 & 11.0 & 0.0 \\
\hline Schlattingen & Grainstone & 1153.49 & 2.2 & 38.6 & 11.2 & 46.0 & 20.4 & 54.3 & 7.0 & 18.3 & 0.0 & 7.6 & 2.0 \\
\hline Schlattingen & Grainstone & 1150.77 & 3.0 & 26.8 & 18.0 & 35.6 & 16.9 & 53.4 & 7.3 & 22.5 & 0.0 & 9.8 & 0.0 \\
\hline Bözberg & Grainstone & 101.6 & 16.6 & 26.6 & 11.6 & 29.0 & 24.8 & 43.4 & 11.0 & 20.7 & 0.0 & 5.8 & 13.2 \\
\hline Bözberg & Grainstone & 100.4 & $9.2(9.8)$ & 45.0 & 2.4 & 47.0 & 28.1 & 47.7 & 6.8 & 17.4 & 0.0 & 7.0 & 4.2 \\
\hline Average & & & 6.5 & 38.4 & 9.1 & 44.6 & 27.3 & 43.2 & 5.6 & 23.6 & 0.3 & 8.8 & 3.2 \\
\hline Average of all ${ }^{\mathrm{d}}$ & & & 3.7 & 27.3 & 7.6 & 34.6 & 15.9 & 38.0 & 5.7 & 38.6 & 1.9 & 8.3 & 1.2 \\
\hline
\end{tabular}

${ }^{\mathrm{a}}$ Porosities in parentheses have been measured by helium pycnometry.

${ }^{\mathrm{b}}$ Estimated porosity prior to cementation excluding intercrystalline mud porosity, i.e. vol $\%$ current porosity + vol $\%$ cements - vol $\%$ dissolution pores

${ }^{\mathrm{c}}$ Dissolution pores that can be unequivocally linked to Hauptmuschelkalk dolomite.

${ }^{\mathrm{d}}$ Calculated from the average of all 25 thin section 


\subsection{Stable isotope analysis}

Stable isotope compositions of five calcite matrix samples indicate a small range in $\delta^{18} \mathrm{O}_{\mathrm{VPDB}}$ from -6.03 to $-4.60 \%$ with an average of $-5.39 \%$, while $\delta^{13} \mathrm{C}$ values show a narrow range and average $+0.41 \%$ o (Fig. 2.6; Table 2.2). These values are similar to those obtained by Schauer and Aigner (1997) on calcites in the Stuttgart region.

Table 2.2. Stable isotopic compositions of early diagenetic calcite cements and calcitic matrix of the Hauptmuschelkalk.

\begin{tabular}{|c|c|c|c|c|}
\hline Borehole & Depth (m) & Sample type $^{\mathrm{a}}$ & $\delta^{13} \mathrm{C}_{\text {VPDB }}(\% o)$ & $\delta^{18} \mathrm{O}_{\mathrm{VPDB}}(\%)$ \\
\hline Böttstein & 172.97 & Calcite cement & 0.92 & -9.00 \\
\hline Böttstein & 172.97 & Calcite cement & 0.78 & -8.34 \\
\hline Böttstein & 172.97 & Calcite cement & 1.15 & -7.78 \\
\hline Böttstein & 160.73 & Calcite cement & -0.03 & -14.31 \\
\hline Bözberg & 121.70 & Calcite cement & 0.63 & -8.12 \\
\hline Bözberg & 128.30 & Calcite cement & -0.31 & -7.45 \\
\hline Bözberg & 128.30 & Calcite cement & 0.36 & -7.14 \\
\hline Bözberg & 128.30 & Calcite cement & -0.03 & -7.90 \\
\hline Bözberg & 114.80 & Calcite cement & 0.46 & -4.21 \\
\hline Schafisheim & 1272.21 & Calcite cement & 0.92 & -6.19 \\
\hline Schafisheim & 1267.33 & Calcite cement & 0.16 & -15.96 \\
\hline Schafisheim & 1267.71 & Calcite cement & 0.02 & -8.40 \\
\hline Siblingen & 230.37 & Calcite cement & 1.23 & -9.05 \\
\hline Siblingen & 230.37 & Calcite cement & 1.26 & -8.96 \\
\hline Siblingen & 231.62 & Calcite cement & 0.91 & -9.49 \\
\hline Weiach & 870.64 & Calcite cement & 0.78 & -11.25 \\
\hline Weiach & 863.15 & Calcite cement & 0.25 & -15.53 \\
\hline Bözberg & 112.84 & Calcite matrix & 0.51 & -4.60 \\
\hline Bözberg & 114.80 & Calcite matrix & 0.33 & -5.04 \\
\hline Bözberg & 116.96 & Calcite matrix & 0.30 & -5.33 \\
\hline Bözberg & 121.95 & Calcite matrix & 0.49 & -5.97 \\
\hline Bözberg & 135.50 & Calcite matrix & 0.44 & -6.03 \\
\hline
\end{tabular}

${ }^{a}$ Calcite cement denotes bulk luminescent cements, whereas blocky cement indicates luminescent cement characterized exclusively by LS . $_{4}$

Bulk $\delta^{18} \mathrm{O}_{\mathrm{VPDB}}$ values of luminescent calcite cements i.e. dog-tooth II, IFS, blocky cements and exclusively blocky cements show a large range from -15.53 to $-4.42 \%$ with an average of $-9.36 \%$ o (Table 2.2). Due to the small size of dog-tooth II and IFS cements, they could not be sampled exclusively from blocky cement and are listed as bulk calcite cement values (Table 2.2). There is no variation in isotope values between the centres and rims of fully cemented cavities. Carbon isotope compositions show a narrower range, with all cements lying between -0.31 and $+1.26 \%$, with an average of $+0.56 \%$. No spatial or vertical trends have been identified and no correlation exists between $\delta^{18} \mathrm{O}$ and $\delta^{13} \mathrm{C}$ values. 


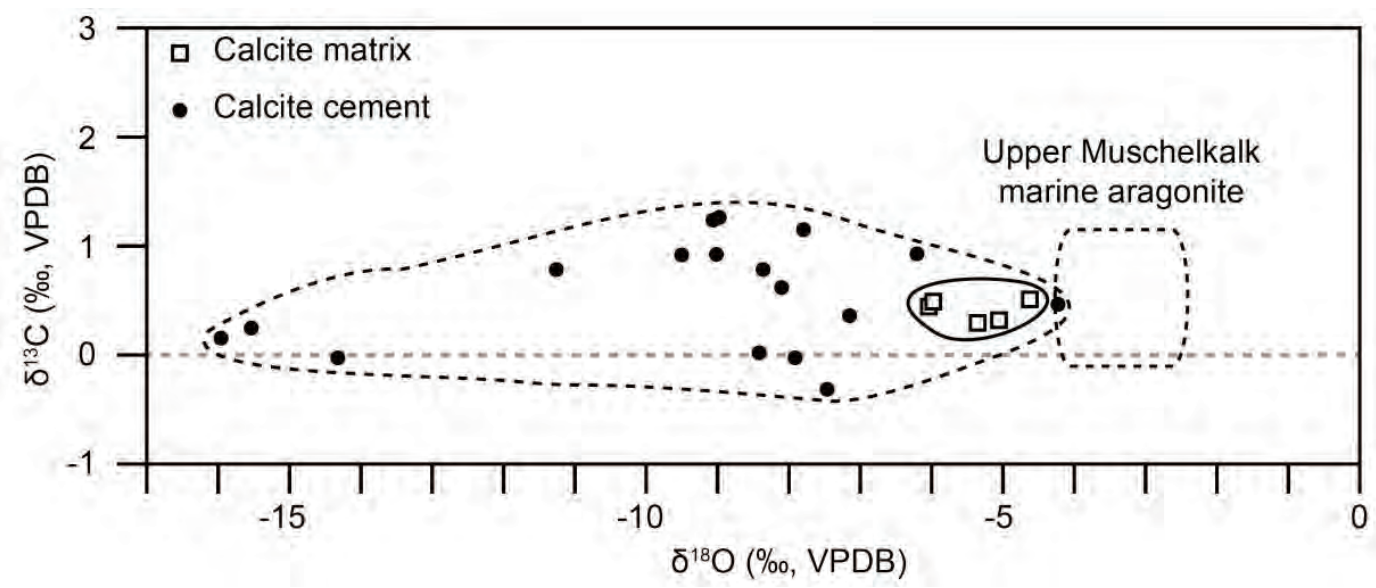

Figure 2.6. Carbon and oxygen isotope compositions of the calcitic matrix and early calcite cements. Dashed box represents early marine aragonite based on the aragonite-water fractionation equation of Kim et al. (2007) and matrix $\delta^{13} \mathrm{C}$ from Franz et al. (2015).

\section{Discussion and interpretation}

\subsection{Characterization of initial Upper Muschelkalk seawaters and sediments}

The initial depositional conditions of Upper Muschelkalk sediments during the early Ladinian must be constrained prior to any diagenetic interpretation. These constraints include the $\delta^{18} \mathrm{O}, \delta^{13} \mathrm{C}$ and ${ }^{87} \mathrm{Sr} /{ }^{86} \mathrm{Sr}$ values as well as temperatures of Upper Muschelkalk sea- and groundwaters and the original mineralogy of the micritic mudstones.

Marine carbon and oxygen isotope signatures of Upper Muschelkalk seawater have been obtained from unaltered brachiopod shells (Korte et al., 2005) and conodonts, brachiopods and fossilized teeth (Franz et al., 2015). Carbon isotope signatures of Middle Triassic marine limestones vary between -0.1 and 1.2\%o within the Central European Basin (Franz et al., 2015). Our analyses of micritic limestones (Table 2.2) fall within this marine $\delta^{13} \mathrm{C}$ range in Switzerland.

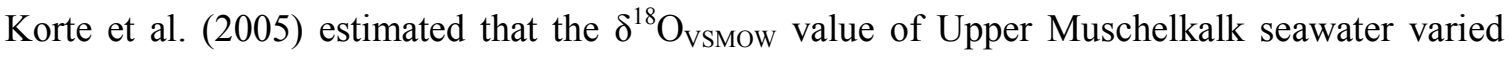
from $0 \%$ in open marine settings to $-2 \%$ in restricted environments receiving greater inputs of meteoric waters. Franz et al. (2015) confirmed these values and identified a basin-wide salinity gradient whereby the epeiric sea became more brackish northwards towards the source of the prograding Lettenkohle environment. During the Anisian/Ladinian, the examined boreholes were located tens of kilometres offshore from the Vindelician High (Fig. 2.1), therefore $\delta^{18} \mathrm{O}_{\mathrm{VSmOW}}$ is constrained to $0 \%$ for the open marine settings of the Upper Muschelkalk of Switzerland.

The stable oxygen isotopic compositions of meteoric waters are influenced by topography, latitude of precipitation, amount of precipitation and local climate (Tucker and Wright, 1990). Precipitation in a semiarid environment at a paleolatitude of $15-20^{\circ} \mathrm{N}$ should produce rainfall with $\delta^{18} \mathrm{O}_{\text {vSMOw }}$ from -4 to $+2 \%$ (Bowen and Revenaugh, 2003). The monsoonal climate of the Upper Muschelkalk, however, may have produced rainfalls with substantially more negative $\delta^{18} \mathrm{O}_{\mathrm{vsmow}}$ 
values due to the "amount effect" (Rozanski et al., 1993). Strongly depleted meteoric cements in the Triassic Southern Alps have been attributed by Mutti and Weissert (1995) to the amount effect, reflecting the Triassic monsoonal environment. The parent waters of these cements reached

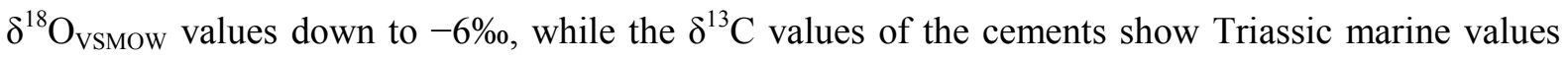
indicating low concentrations of dissolved organic carbon (DOC) in meteoric fluids (Mutti and Weissert, 1995).

Based on the $\delta^{18} \mathrm{O}$ value of unaltered brachiopod fossils in the CEB and on a seawater $\delta^{18} \mathrm{O}_{\text {VSMOW }}$ of $0 \%$, seawater temperatures are estimated to have been between 25 and $37{ }^{\circ} \mathrm{C}$ (Korte et al., 2005). In the Persian Gulf, an analog of a shallow, low-altitude, semi-enclosed sea in an arid environment, yearly sea surface temperatures average around $27^{\circ} \mathrm{C}$, with maxima and minima $\left(\sim 20-33{ }^{\circ} \mathrm{C}\right)$ falling mostly within the temperature range of Korte et al. (2005) (Sheppard et al., 2010). Yearly average groundwater temperatures around the Persian Gulf are slightly higher at $32{ }^{\circ} \mathrm{C}$ (Wood et al., 2005). This temperature range will be used throughout the present study when calculating isotope fractionation with respect to seawater.

Radiogenic strontium analyses have been obtained from unaltered brachiopods, conodont apatite and tooth apatite (Korte et al., 2003; Franz et al., 2015). Spatial variations of ${ }^{87} \mathrm{Sr} /{ }^{86} \mathrm{Sr}$ occur in tandem with the Upper Muschelkalk Sea salinity gradient, whereby southern marine waters show values of 0.70775 and increase northwards to 0.7084 in waters associated with the deposition of the Lettenkohle (Franz et al., 2015). The influence of highly radiogenic meteoric fluids from the Vindelician High $\left({ }^{87} \mathrm{Sr} /{ }^{86} \mathrm{Sr}=0.711-0.718\right)$ has been attributed to account for slight increases in Upper Muschelkalk marine ${ }^{87} \mathrm{Sr} /{ }^{86} \mathrm{Sr}$ during the Middle Triassic (Korte et al., 2003). Again due to the open marine and southern settings of Switzerland, seawater ${ }^{87} \mathrm{Sr} /{ }^{86} \mathrm{Sr}$ is interpreted to be 0.70775 during the deposition of most of the Swiss Upper Muschelkalk.

Using the above parameters and applying the aragonite-water fractionation equation of Kim et al. (2007), we calculate that marine aragonitic sediments in Switzerland should have had $\delta^{18} \mathrm{O}_{\mathrm{vSmOw}}$ values between -2.41 and $-4.27 \%$, $\delta{ }^{13} \mathrm{C}_{\mathrm{VPDB}}$ between 0 and $+1 \%$, and a ${ }^{87} \mathrm{Sr} /{ }^{86} \mathrm{Sr}$ value of 0.70775 upon deposition and prior to any diagenesis (Fig. 2.6).

During the Middle Triassic, aragonite and HMC were the dominant inorganic carbonate precipitates of seawaters (Hardie, 1996). Studies of the Middle Triassic Dolomites of the Southern Italian Alps (Preto et al., 2009), the Upper Muschelkalk deposits of Catalonia (Tucker and Marshall, 2004) and in Middle Triassic carbonate ramp deposits in Hungary (Török, 2000) have shown that aragonite and HMC were the dominant mineralogies of the micritic mudstones of Middle Triassic low-latitude, warm climate central European carbonate ramps. It follows that the initial sediments of the semi-arid Upper Muschelkalk of Switzerland were also composed of aragonite and HMC. 


\subsection{Comparison of early diagenesis in Germany and Switzerland}

Early diagenesis of the Upper Muschelkalk unit in Germany has been examined by several authors (Bachmann, 1973; Braun, 2003; Palermo et al., 2012). They have identified a similar sequence of diagenetic events as presented in the present study. Diagenesis began with an isopachous circumgranular bladed cement encrusting most components ( $A_{1}$ cement). This was followed by significant leaching of aragonite bioclasts and ooids, attributed to fresh water exposure or to aragonite undersaturation in marine pore fluids (Braun, 2003). Following leaching, another isopachous cement with shorter crystals than the earlier bladed cement precipitated around and within bioclasts and their moulds $\left(A_{2}\right.$ cement). Both cements are interpreted as having resulted from phreatic marine diagenesis (Braun, 2003). Then a dogtooth cement was precipitated ( $B_{1}$ cement), with luminescence distinctly different to that of the $A_{1}$ and $A_{2}$ cements. A blocky cement that increases in crystal size towards the interior of pores was then precipitated within and around bioclasts ( $\mathrm{B}_{2}$ Cement). Both $\mathrm{B}$ cements are interpreted as shallow burial cements (Braun, 2003). Minor amounts of dolomites eventually precipitated within some open pore spaces. All events occurred prior to stylolitization (Bachmann, 1973; Braun, 2003; Palermo et al., 2012).

Based on the petrographic images and the paragenetic sequence of the three above-cited studies, we can confidently correlate German $A_{1}$ cement with Swiss isopachous bladed cement, $A_{2}$ cement with fluorescent dog-tooth cement, $\mathrm{B}_{1}$ with dog-tooth cement II and $\mathrm{B}_{2}$ cement with blocky cement. Aragonite leaching appears to have occurred at the same time within the two countries and was therefore likely produced by the same process. Spotty dolomitization exhibits similarities with Hauptmuschelkalk dolomites. However, due to the massive matrix dolomitization that is present in Switzerland but not in the studied sections in Germany, we cannot definitively correlate spotty dolomitization with Hauptmuschelkalk dolomitization.

\subsection{Marine diagenesis}

Diagenesis in Germany and Switzerland initially took place in the marine diagenetic realm (Fig. 2.7A, B). Pyritization and micritization of the aragonitic precursor occurred directly after deposition at the sediment-water interface by bacterial sulphate-reduction and boring micro-organisms (Berner, 1985; Tucker and Wright, 1990). Following micritization, elongated aragonite/high-magnesium calcite (HMC) bladed cements precipitated on most bivalves and brachiopods, while many crinoids were cemented by inclusion-rich syntaxial cements. The bright fluorescence and abundant inclusions in both these cements point to marine pore-fluids rich in dissolved humic substances (Ramseyer et al., 1997). Non-luminescent patches, within otherwise mottled dull luminescent zones (Fig. 2.3A), showing strong fluorescence within various locations of bladed and inclusion-rich syntaxial cements are interpreted to reflect the original cement compositions. They indicate that the original parent pore fluids were oxidizing and free from sufficient concentrations $\mathrm{Mn}^{2+}$ to induce luminescence, while the 
dull mottled luminescence suggests that cements recrystallized in a suboxic environment containing dissolved $\mathrm{Mn}^{2+}$ (Frank et al., 1982).
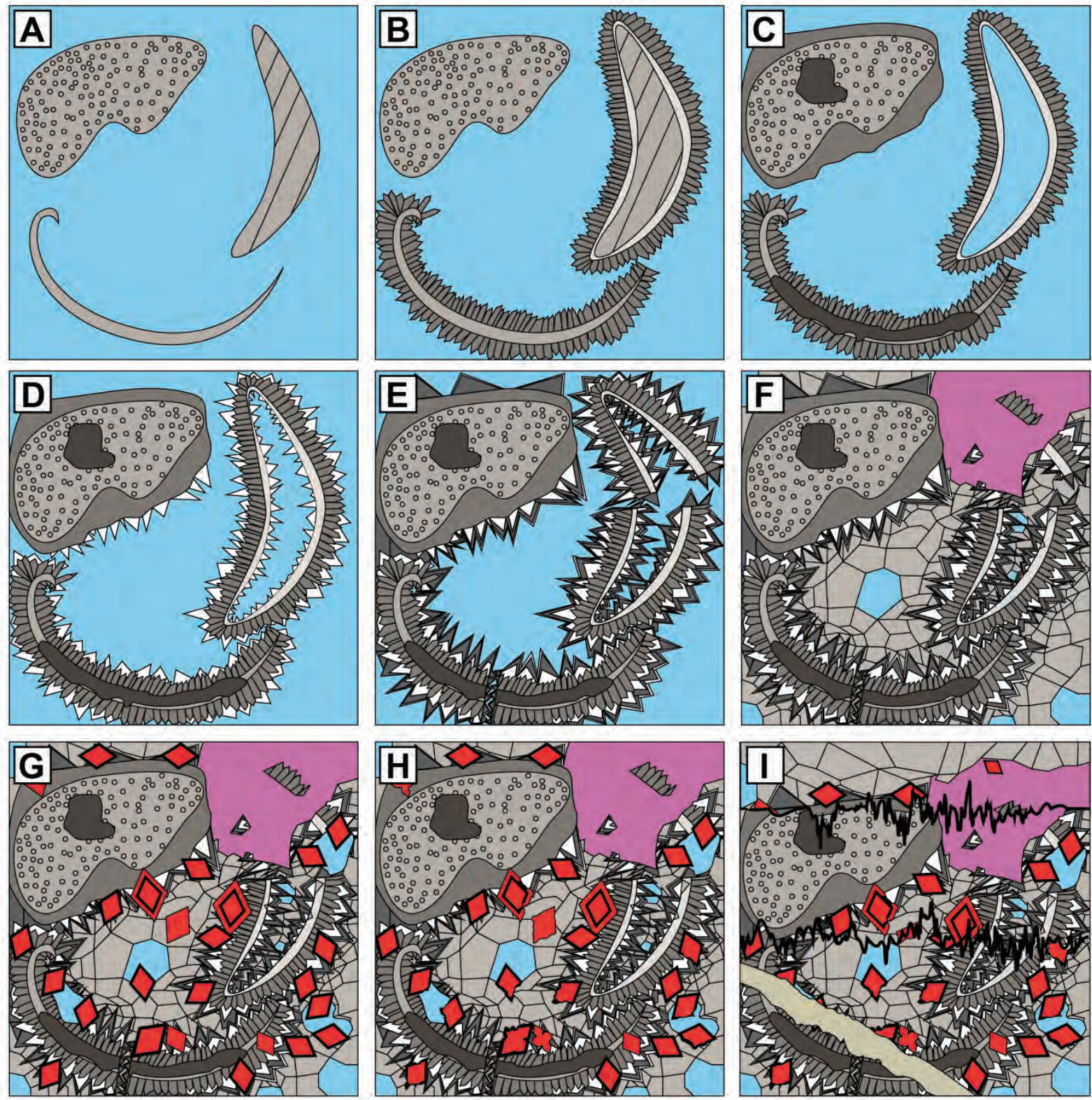

Open pores $\square$ Bladed cement

$\square$ Bioclast $\square$ Silicification

Micritization $\triangle$ Fluorescent cement

$\triangle$ Dog-tooth cement II

[] Blocky cement

Hauptmuschelkalk

dolomite

Anhydrite cement

Dedolomite

Fracture

\section{$\triangle$ Fluorescent cement}

Figure 2.7. Schematic reconstruction of early diagenetic events. A) A crinoid (top left), aragonitic bivalve (right) and brachiopod (bottom) are deposited. B) Bladed cements precipitate on brachiopods and micritized bivalves. C) Aragonitic fossils are leached and crinoids and brachiopods are silicified. D) Fluorescent dog-tooth cements precipitate on the exterior and interior of fossils and moulds. E) Luminescent stage 2 and 3 cements precipitate. F) Blocky calcite cements fill most pores and are replaced by anhydrite cement. G) Hauptmuschelkalk dolomites (HMD) precipitate. H) Dedolomitization affects most HMD. I) Stylolites and calcite-filled fractures cross-cut all diagenetic features. 


\subsection{Mixing-zone and marine burial diagenesis}

Microspar formation, silicification, dissolution and a change in crystal morphologies following marine diagenesis (Fig. 2.7C,D) all suggest a modification of connate seawaters. In particular, these are all processes which occur during marine/meteoric mixing (Knauth, 1979; Ward and Halley, 1985; Melim et al., 2004) or during shallow-burial diagenesis in seawater (Noble and Van Stempvoort, 1989; Melim et al., 1995; Munnecke et al., 1997; Melim et al., 2001). Microspar formation is intrinsically linked with aragonite-calcite neomorphism, regardless of the diagenetic environment (Munnecke et al., 1997). The $\delta^{18} \mathrm{O}_{\mathrm{VPDB}}$ of the Hauptmuschelkalk LMC microspar is up to $\sim 3 \%$ lower than Upper Muschelkalk marine carbonate, indicating high temperatures or waters with light $\delta^{18} \mathrm{O}$ ratios during neomorphism. Marine water with a $\delta^{18} \mathrm{O}_{\text {VSMOw }}$ of $0 \%$ requires a temperature of $44{ }^{\circ} \mathrm{C}$ to precipitate LMC with a $\delta^{18} \mathrm{O}_{\mathrm{VPDB}}$ of $-6.02 \%$. This would suggest neomorphism occurred during the early Jurassic after a few hundred meters of burial according to the burial curves of Mazurek et al. (2006). However, no aragonite has been preserved in any dolomitized sections and almost none of the documented diagenetic products following marine diagenesis (Chapter 2.4) show evidence of significant recrystallization or precipitation from fluids saturated in aragonite. Therefore, it is unlikely that the matrix remained aragonitic until the early Jurassic. The observed depleted $\delta^{18} \mathrm{O}$ values of the matrix (Fig. 2.6) must reflect neomorphism in waters with $\delta^{18} \mathrm{O}$ varying between marine connate water and depleted meteoric values rather than shallow-burial diagenesis in seawater. Neomorphism in solely meteoric water is rejected based on the known radiogenic meteoric end-member, which would have imparted ${ }^{87} \mathrm{Sr} /{ }^{86} \mathrm{Sr}$ values considerably higher than the current values of the Upper Muschelkalk matrix $\left({ }^{87} \mathrm{Sr} /{ }^{86} \mathrm{Sr} \approx 0.7083\right.$; Diamond et al., 2013). The slightly elevated ${ }^{87} \mathrm{Sr} /{ }^{86} \mathrm{Sr}$ values of the LMC matrix, compared with Upper Muschelkalk seawater additionally support a mixed-water origin.

The mixing of seawater with silica-saturated meteoric groundwaters is often associated with the formation of chert and silicification in shallow-marine carbonates (Knauth, 1979, 1994; ManningBerg and Kah, 2017). However, the oxidation of organic matter and sulphate reduction during shallow burial in exclusively marine pore fluids can also result in quartz replacement and precipitation (Noble and Van Stempvoort, 1989). The source of silica in the Trigonodus Dolomit is unknown. Bachmann (1973) suggested volcanic activity, clay diagenesis and sponge spicule dissolution. Regarding the latter, sponge spicules have been observed by Merki (1961) in Swiss Upper Muschelkalk sediments.

Silicification in the Trigonodus Dolomit occurred immediately prior to aragonite/HMC-LMC neomorphism, aragonite leaching and prior to matrix dolomitization. Several points of evidence support this timing: the presence of microdolomite inclusions in crinoid ossicles, which indicate that the crinoids had not recrystallized to LMC prior to silicification (Lohmann and Meyers, 1977); the presence of partially silicified bladed cements (Fig. 2.4E) and chertified anhydrites; the lack of moulds in chertified carbonates; and the presence of well-preserved chertified ooids (Fig. $2.4 \mathrm{H}$ ). The 
non-fabric-selective nature of chertification further indicates that silicification was not an early diagenetic feature related to depositional facies. The horizontal layering of many chert nodules parallel to bedding at the top of the Trigonodus Dolomit may be related to the development of a horizontal mixing zone (Knauth, 1979), whereby a freshwater lens may have developed over top of connate seawaters during a shoreline progradation into the southern CEB. However, chert nodule formation, like most diagenetic processes, can occur anywhere within the Upper Muschelkalk (Merki, 1961; Brüderlin, 1971) suggesting that chertification occurred due to a basin-wide mixing of pore fluids, or that chert nodules are unrelated to one another and formed immediately after marine cementation and shallow burial.

Localized dissolution of aragonite bioclasts can take place in bulk fluids super- and undersaturated in aragonite. Aragonite undersaturation and dissolution readily occurs in mixing-zones (Smart et al., 1988). Alternatively, many authors have recognized that $\mathrm{pH}$ decline during oxidation of organic matter can cause localized in-situ dissolution and neomorphism in the presence of bulk aragonite-saturated fluids (Aller, 1982; Walter et al., 1993; Hendry et al., 1995). Oxidation of organic matter occurs relatively rapidly following burial within the first 10-20 cm below the sediment-water interface (Aller, 1982; Canfield, 1993) and can lead to widespread dissolution of bioclastic beds (Cherns and Wright, 2000, 2009). However, aragonitic bioclasts can also be preserved by bottomwater anoxia in low-energy environments, by bioturbation transporting shells below the dissolution zone, and by rapid burial due to storm events (Aller, 1982; Cherns et al., 2008). The latter may well have occurred in the case of the Hauptmuschelkalk, where most of the bioclastic beds are centimetredecimetre thick tempestites (Aigner, 1985; Franz et al., 2015).

Several authors have attributed aragonite leaching in the Hauptmuschelkalk to periods of subaerial exposure (Braun, 2003; Palermo et al., 2012). While some shoal bodies during sea-level lowstands may have been exposed to meteoric water through rainfall, all bioclastic beds regardless of their depositional environment show dissolution. This includes distal- and mid-ramp facies, which would have required large basin-wide subaerial surfaces to frequently develop during the deposition of the entire Upper Muschelkalk. Therefore, early meteoric leaching by subaerial exposure is unlikely to have produced the significant amounts of aragonite dissolution in the Hauptmuschelkalk.

Aragonite dissolution in the Hauptmuschelkalk predates the precipitation of fluorescent dog-tooth cement, which in turn generally predates shell fracturing by compaction. The strong fluorescence of dog-tooth cements must be related to a sudden increase in organic substances in the surrounding pore water. Dissolution of organic-rich bioclasts will have locally liberated significant amounts of organic compounds, which may have been incorporated into adjacent fluorescent dog-tooth cements. None of the cements precipitated after fluorescent dog-tooth cement show fluorescence, indicating that the pore fluids during those later stages were devoid of humic substances. This supports the hypothesis of a local, readily exhaustible source for the fluorescence-generating organic matter, rather than input via organic rich meteoric waters. Despite its overall moderate luminescence, some fluorescent dog-tooth 
cements contain non-luminescence zones that display very bright fluorescence (Fig. 2.3A). We interpret these patches as indications that the cement was initially precipitated in an oxidizing environment, as bladed cements, and later recrystallized in reducing pore fluids. Oxidizing fluids and bright fluorescence both argue for early aragonite dissolution during shallow burial.

The petrographic evidence in Chapter 2.4.2 indicates that chertification and silicification occurred prior to aragonite leaching and fluorescent dog-tooth cementation during shallow burial, and therefore likely also reflects shallow burial diagenesis. Isotopic studies of the fluorescent dog-tooth cements could provide additional confirmation of the diagenetic environment; however, until clear nonrecrystallized fluorescent dog-tooth cements are found, the isotopic values of these cements should be treated with caution. Isotopic analyses of the microspar indicate that it recrystallized due to the mixing of meteoric and marine fluids. In the absence of any strong evidence of meteoric waters during aragonite leaching and silicification, it is most likely that neomorphism and the mixing of waters occurred after shallow burial diagenesis in marine pore fluids.

\subsection{Meteoric diagenesis}

Dog-tooth II and blocky cements in the Upper Muschelkalk of Germany (B-cement) have been ascribed to burial diagenesis in the phreatic marine environment prior to dolomitization and stylolitization (Fig. 2.7E) (Bachmann, 1973; Braun, 2003; Palermo et al., 2012). Maximum burial depths of the Upper Muschelkalk upon dolomitization could not have been $>70 \mathrm{~m}$ based on early dolomitization models (Schauer and Aigner, 1997; Koehrer et al., 2010). Despite stabilization by early marine and shallow burial cements, many bioclasts were fractured by early compaction and then additionally enveloped by luminescent cements.

If calcite cements had precipitated in connate seawater at shallow depths, their $\delta^{18} \mathrm{O}_{\mathrm{VPDB}}$ values should be significantly higher than the observed average $\delta^{18} \mathrm{O}_{\mathrm{VPDB}}$ of $-9.36 \%$ (Table 2.2). It follows that the calcite cements must have recrystallized or formed at higher temperatures, or precipitated from ${ }^{18} \mathrm{O}$-depleted waters. Most calcite cements show no evidence of recrystallization. However, the three most depleted samples (with $\delta^{18} \mathrm{O}$ of $-15.96,-15.53$ and -14.31) may have been indeed reset by recrystallization or represent late stage calcites, which are characterized by $\delta^{18} \mathrm{O}_{\mathrm{VPDB}}$ values lower than $-12 \%$ and negative $\delta^{13} \mathrm{C}_{\mathrm{VPDB}}$ ratios (Diamond et al., 2013). Omitting these samples still produces an average $\delta^{18} \mathrm{O}$ of $-8.09 \%$. According to the calcite-water fractionation equation of Friedman and O'Neil (1977), such a low value would require temperatures in excess of $55{ }^{\circ} \mathrm{C}$ and water with $\delta^{18} \mathrm{O}_{\text {VSMOw }}$ of $0 \%$. A slightly more depleted seawater with $\delta^{18} \mathrm{O}$ of $-2 \%$ would still imply a temperature around $45{ }^{\circ} \mathrm{C}$. These temperatures are unreasonably high for seawater at such shallow burial depths. The calcite cements must therefore reflect ${ }^{18} \mathrm{O}$-depleted waters rather than elevated precipitation temperatures. Using the same fractionation equation and taking a groundwater temperature equal to $32{ }^{\circ} \mathrm{C}$, as in the Persian Gulf analog (above), the luminescent calcitic cements 
are calculated to have precipitated from fluids with an average $\delta^{18} \mathrm{O}_{\text {VSMOW }}$ of $-4.40 \%$. This value falls within the range of Middle Triassic monsoonal meteoric waters (Mutti and Weissert, 1995) and thus represents a strong influence of meteoric, rather than connate, fluids in the formation of the early cements. The $\delta^{13} \mathrm{C}_{\mathrm{VPDB}}$ values of the luminescent cements reflect buffering by dissolved marine carbonates. Their lack of fluorescence further confirms that the meteoric fluids contained little DOC.

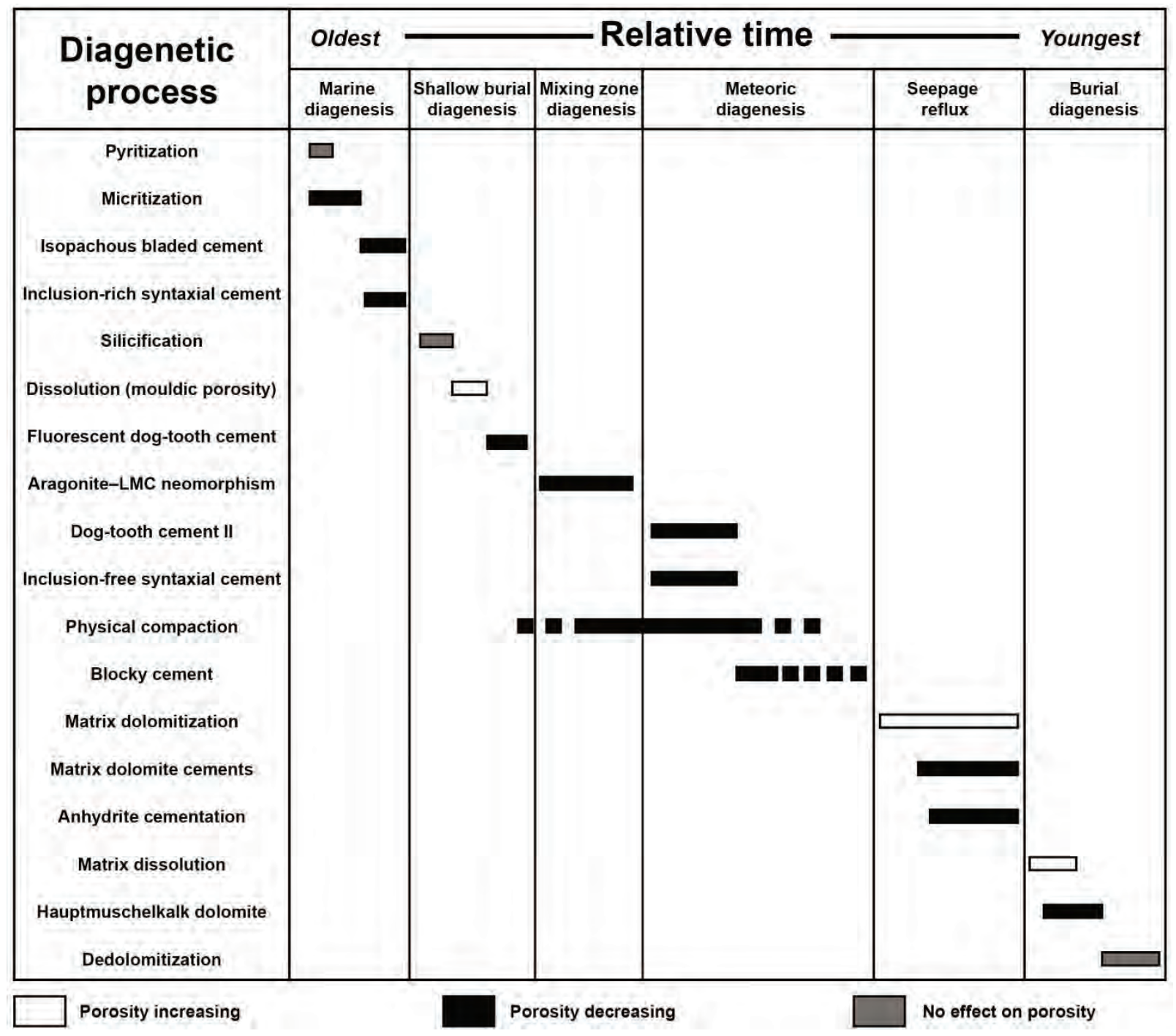

Figure 2.8. Paragenetic sequence of early diagenesis (prior to stylolitization) of the Upper Muschelkalk in northern Switzerland.

\subsection{Anhydrite cementation and the timing of matrix dolomitization}

Anhydrite cements provide the most definitive evidence regarding the timing of matrix dolomitization relative to early diagenesis (Fig. 2.7F). Anhydrite cementation is a common feature associated with seepage reflux dolomites (Ruppel and Cander, 1988; Rahimpour-Bonab et al., 2010), whereby $\mathrm{Ca}^{2+}$ liberated by dolomitization reacts with sulphate rich refluxing brines (Machel, 2004). 
Dissolution and replacement by anhydrite along the edges of all generations of luminescent cements in Schafisheim indicates that matrix dolomitization occurred following the conclusion of meteoric cementation. The lack of early calcite cements overgrowing matrix dolomites in any other boreholes is further evidence for matrix dolomitization postdating all early calcite cements. Only Hauptmuschelkalk dolomites have precipitated following anhydrite cementation and prior to stylolitization (Fig. 2.7G,H,I). It is unknown whether anhydrite cementation originally occurred only in the western boreholes, or whether it was once ubiquitous prior to telogenetic leaching. According to generalized hydrogeologic models of dolomitization, the zone of greatest anhydrite cementation often occurs at the dolomitization front; however, this zone is not stable and it is susceptible to modification by any subsequent fluids (Jones and Xiao, 2005; Al-Helal et al., 2012). Thus, loss of anhydrite by leaching in the eastern boreholes remains a possibility.

\subsection{Paleoenvironmental interpretation of Upper Muschelkalk early diagenesis}

The petrographic and isotopic evidence presented above indicates that the pore fluids in the Upper Muschelkalk carbonates of Switzerland and southern Germany changed from marine to meteoric prior to matrix dolomitization (Fig. 2.8). Such seawater-meteoric or even seawater-meteoric-seawater transitions are not uncommon in the diagenesis of shallow-water carbonates. They often take the form of regressive-transgressive-regressive cycles (Burchette and Wright, 1992) or freshwater lenses flowing underneath impermeable beds or crusts (Chafetz et al., 1988; Tobin and Walker, 1994). No evidence has been found of beds or cemented crusts that could have served as impermeable caps above the Trigonodus Dolomit. Nevertheless, such a bed could possibly have been eroded by the prograding Lettenkohle environment. In contrast, there is abundant evidence for transgressiveregressive cycles and subaerial exposure surfaces leading up to the end of the deposition of the Upper Muschelkalk (Schauer and Aigner, 1997; Koehrer et al., 2010). The associated sea-level fall would have induced infiltration of meteoric groundwater from either the Vindelician High or the prograding Lettenkohle environment (Fig. 2.9A). Due to the shallow nature of the epeiric sea, and the very low angle of inclination of the carbonate ramp $\left(<0.01^{\circ}\right.$; Borkhataria et al., 2005), even a one meter drop in sea level would have subaerially exposed vast areas of the formation. For example, a ramp angle of $0.005^{\circ}$ and a sea-level drop of $\sim 5 \mathrm{~m}$ would have exposed the entire $55 \mathrm{~km}$ stretch of the Upper Muschelkalk between the Schafisheim and Schlattingen boreholes (Fig. 2.9B). Such a regional sealevel drop would have exposed the top of the eastern Schlattingen sediments to the vadose diagenetic environment. However, no evidence of vadose diagenesis exists, presumably due to the destructive nature of matrix dolomitization or to erosion by the Lettenkohle. The western extent of meteoric diagenesis is unknown, although preliminary examination of thin sections from north-central Switzerland appears to show preserved ooids without any signs of meteoric leaching. 

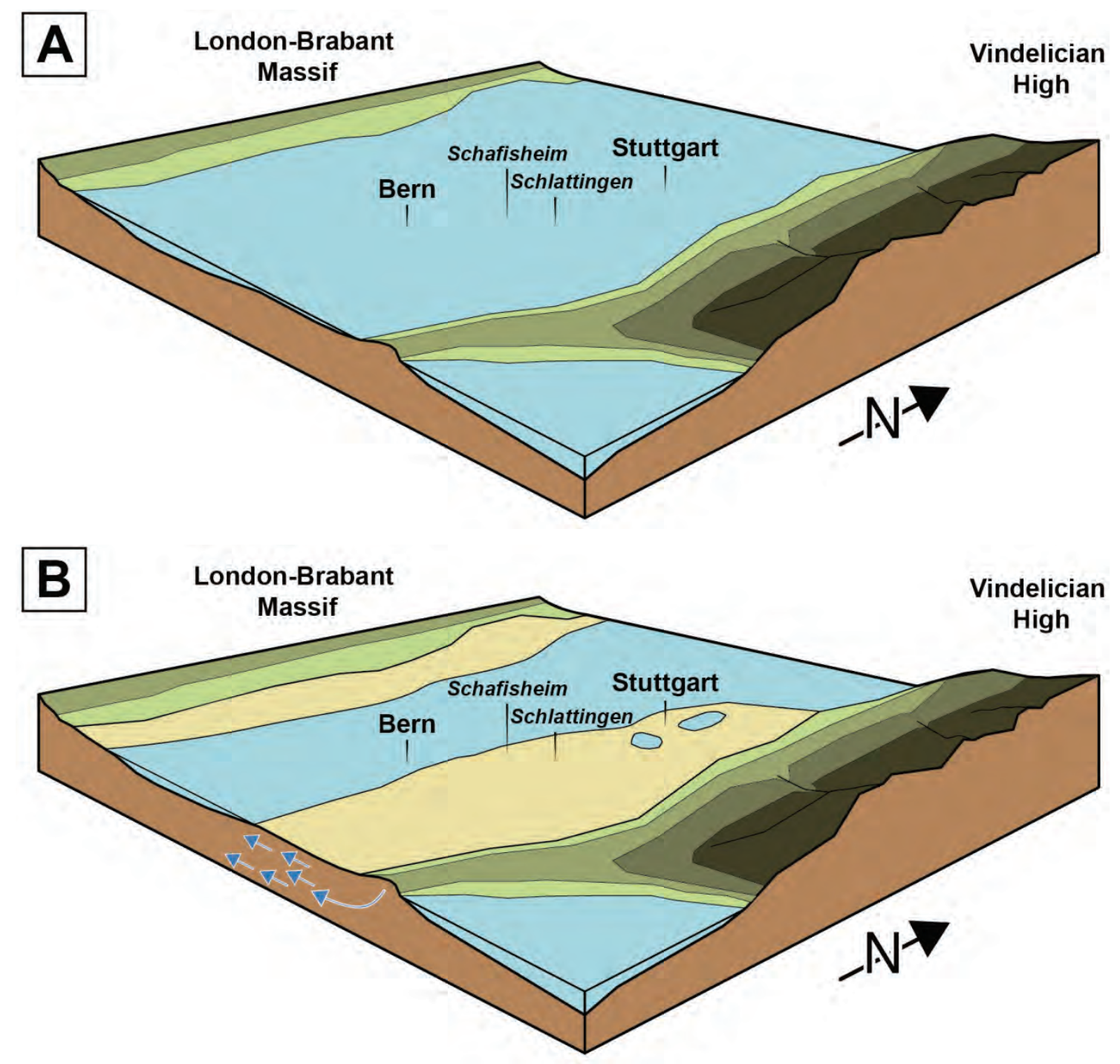

Figure 2.9. Paleohydrological reconstruction of the southern CEB based on Ziegler (1990) and this study. A) Paleogeographic setting during the late Anisian. B) Paleogeographic setting during the early Ladinian at the conclusion of the deposition of the Upper Muschelkalk. The epeiric sea retreats into a central seaway and sediments east of Bern and northwards towards Stuttgart are subaerially exposed. Owing to the establishment of topography-induced hydraulic gradients, groundwater flows westwards from the Vindelician High into the basin.

\subsection{Porosity modification by early diagenesis}

The porosity of modern carbonate sediments upon deposition varies from 40 to $75 \%$, depending on the amount of bioclastic particles, sediment size and mud content (Enos and Sawatsky, 1981). Whereas mudstones are the most porous beds at deposition, they are particularly sensitive to early burial compaction and can lose $10 \%$ of their initial porosity during the first $50 \mathrm{~m}$ of burial (Matter et al., 1975). Neomorphism of aragonite/HMC to LMC during early meteoric diagenesis may decrease porosity by absolute values of 5-20\% (Schmoker and Hester, 1986), while neomorphism of aragonite/HMC to LMC during shallow burial diagenesis can result in porosities $<5 \%$ after only a few meters of burial (Lasemi and Sandberg, 1984). The Upper Muschelkalk was buried to at most $70 \mathrm{~m}$ when it was first infiltrated by meteoric groundwaters. Early compaction and neomorphism in mixed 
meteoric/marine fluids would have left mudstones with porosities around $50 \%$ prior to significant burial. Therefore, the present-day $<5 \%$ porosity of the mudstone matrix in Switzerland and Germany (Braun, 2003; Diamond et al., 2013) is interpreted to reflect chemical and physical compaction at depth rather than early diagenesis.

The bioclastic beds in the Upper Muschelkalk followed different diagenetic pathways (Fig. 2.10). Early compaction and neomorphism were not important porosity-reducing processes. Marine diagenesis (bladed cements + IRS) was responsible for an absolute porosity reduction of on average $7.5 \mathrm{vol} \%$ in all bioclastic beds prior to any meteoric groundwater infiltration. Inclusion-rich syntaxial cements were limited to crinoid-rich beds found mostly at the base of the Upper Muschelkalk, whereas bladed cements are present equally in all beds. Crinoid content in bioclastic beds decreases from the base to the top of the Hauptmuschelkalk (Diamond et al., 2013), in line with a stratigraphically upwards environmental shift from a crinoid ramp to a shelly/ooid ramp (Aigner, 1985). This demonstrates a facies control on diagenesis, which has also been noted in marine cements of the Upper Muschelkalk of Germany (Palermo et al., 2012).

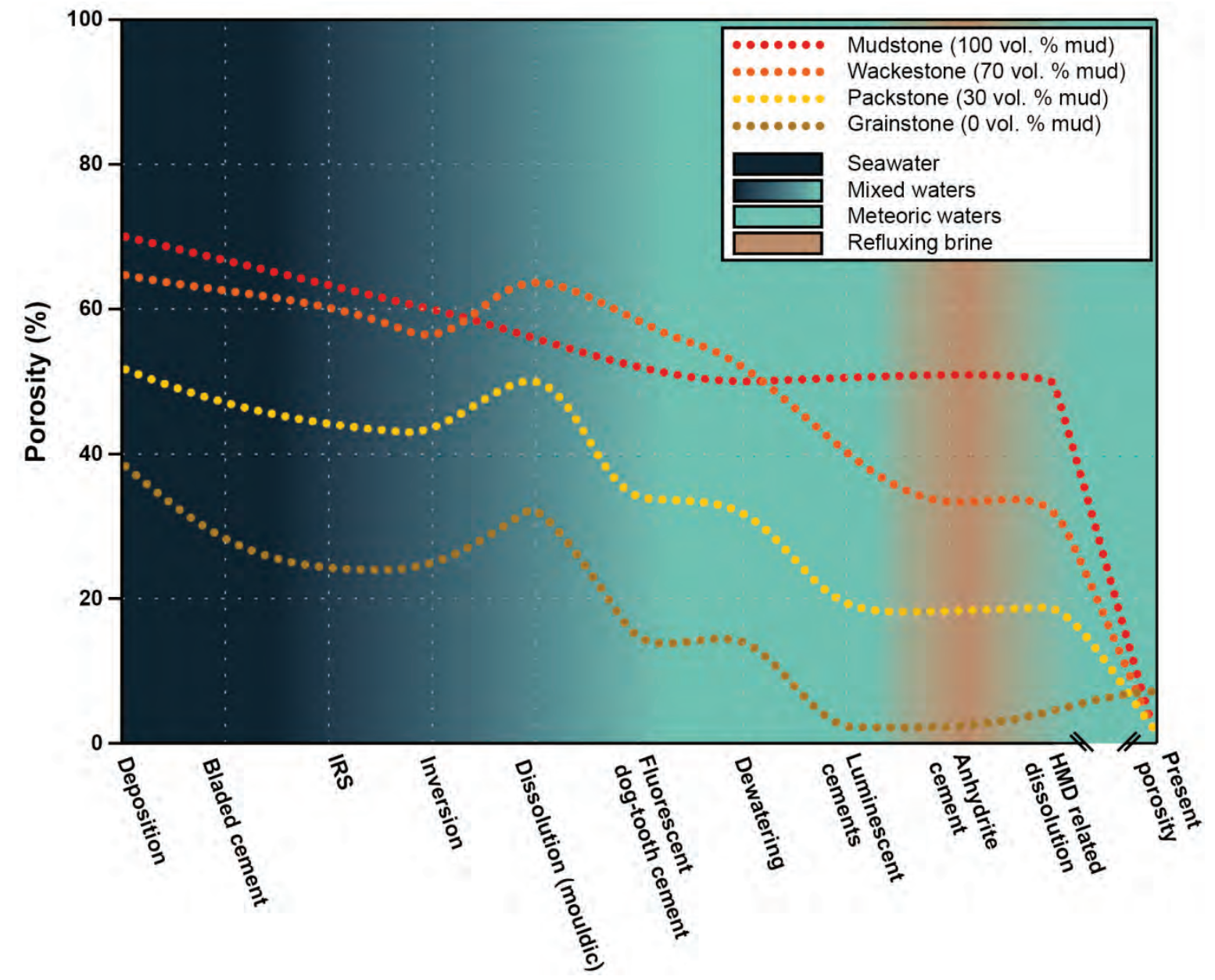

Figure 2.10. Interpreted effects of diagenetic events on porosity in various rock types. All porosity-modifying processes are quantified using point-counted values in Table 1 . Initial porosity $=$ Pre-cement grain porosity $($ Table 1$)+$ mud porosity $(70$ vol $\%)$. 
Shallow burial diagenesis (fluorescent dog-tooth cements - mouldic pores) resulted in an average $4.8 \mathrm{vol} \%$ reduction of available pore volume with most occlusion due to fluorescent dog-tooth cements. Fluorescent dog-tooth cement was not fabric-selective and it coated grains as well as occluding mouldic pores that had formed via dissolution during shallow burial. Aragonite leaching increased porosity by $8.3 \mathrm{vol} \%$ on average and could potentially increase porosity by up to $17 \mathrm{vol} \%$ (Table 2.1). Dissolution in Germany appears to have created significantly greater amounts of porosity than the average 8 vol\% recorded in Switzerland (Braun, 2003) and is the greatest source of porosity in German bioclastic beds (Palermo et al., 2012). This perhaps reflects differences in the faunal assemblages that compose shoals and tempestites in Switzerland and Germany. Neither Braun (2003) nor Ruf and Aigner (2004) note any crinoids within the shoal or shoal associated bodies; however, crinoidal grainstones constitute the facies with the best reservoir properties in the study area of Palermo et al. (2012). Switzerland does not have any facies equivalent to shoal associated crinoidal grainstones (Diamond et al., 2013), and none of the crinoidal facies experienced crino-mouldic dissolution or vug formation as they have in Germany (Palermo et al., 2012). Additionally, ooid shoals, which are absent in undolomitized sections of Switzerland (Merki, 1961; Diamond et al., 2013) but common along the German paleoshoreline (Aigner, 1985), underwent both early aragonitic leaching and late telogenetic leaching (Braun, 2003; Palermo et al., 2012).

Meteoric cementation (luminescent cements) accounted for the final major stage of porosity occlusion within the Upper Muschelkalk. Approximately 13.4 vol\% of the pore space was occluded by luminescent cements prior to dolomitization. The result was that grainstone beds had average porosities of $6 \%$ following dolomitization and anhydrite cementation. Present-day porosities of the non-dolomitized limestones in Switzerland may be slightly higher due to anhydrite leaching by latestage telogenetic meteoric waters. Contrastingly, grainstone and packstone beds in Germany commonly exhibit porosities and permeabilities of 9-23\% and 21-700 mD (Palermo et al., 2012).

It has been widely recognized that facies play a crucial role in the reservoir characteristics of the limestone portions of the Upper Muschelkalk (Braun, 2003; Ruf and Aigner, 2004; Palermo et al., 2012). Swiss bioclastic facies-assemblages are mostly of distal- to midramp tempestites with few shoal bodies (Diamond et al., 2013) whereas Germanic bioclastic facies are dominated by meter-scale oolite/shelly shoals and associated beds (Aigner, 1982; Braun, 2003). Porosity in Upper Muschelkalk tempestites is dominated by mouldic pores, which are poorly interconnected due to mud contents and upwards decreases in bioclast grainsizes (Braun, 2003). Without additional dissolution enhancing porosity from fracturing and late meteoric leaching, tempestite porosities average $<5 \%$ (Braun, 2003), which is comparable to the low porosities observed in the tempestites of the present study. Both packstone and wackestone tempestites have lower porosities and permeabilities than shoal bodies (Braun, 2003; Palermo et al., 2012), therefore making shoals more susceptible to early diagenetic leaching and late telogenetic fluid flow. 
The similarities between Switzerland and Germany with respect to cement phases, paragenesis and proportions of cements seem to rule out diagenetic processes as the cause of the observed differences in reservoir properties of the Upper Muschelkalk between the two countries. Rather, we conclude that differences in facies may account for the differences in reservoir properties between Switzerland and Germany.

\section{Conclusions}

The sequence of early diagenetic events (pre-stylolitization) in the Swiss Upper Muschelkalk appears to be identical to that in the southern German Upper Muschelkalk. Bladed isopachous cements and inclusion rich syntaxial cement are the earliest generations of cements. Both precipitated in a marine environment under oxidizing conditions rich in DOC.

The oxygen isotope compositions of the LMC matrix indicate that neomorphism from aragonite/HMC occurred at low temperatures in a mixture of meteoric groundwaters and connate seawaters, after marine diagenesis. The meteoric groundwaters were depleted in ${ }^{18} \mathrm{O}$ and low in DOC. Chertification and silicification occurred prior to matrix neomorphism and aragonite dissolution. Aragonite dissolved throughout all facies regardless of water depth. Humic substances released by this dissolution were incorporated in brightly fluorescing dog-tooth cements, which precipitated both on the exteriors and interiors of moulds.

Earlier workers hypothesized that early diagenesis occurred in connate seawaters and that, apart from localized subaerial exposure during deposition, meteoric waters first infiltrated the buried mass of Upper Muschelkalk well after dolomitization. In contrast, our study of the oxygen isotope compositions of dog-tooth II and blocky calcite cements shows that they precipitated at low temperatures from reducing, ${ }^{18} \mathrm{O}$ depleted meteoric groundwaters prior to dolomitization. The concurrence of early Ladinian regressive cycles with the low angle of the carbonate ramp points to the nearby Vindelician High as the source of meteoric groundwater that percolated far into the southern Central European Basin. Matrix dolomitization followed meteoric cementation, demonstrating an environmental shift and sea-level rise prior to the deposition of the overlying terrestrial-brackish Lettenkohle sediments.

Although the same diagenetic events occurred in Switzerland and Germany, the nature and distribution of facies differ in the two areas. These differences in facies explain the differences in reservoir properties of the Upper Muschelkalk limestones. Whereas mudstones throughout the southern Central European Basin have been compacted by burial, such that porosities are much less than $5 \mathrm{vol} \%$, grainstones have retained the porosity they had at the end of early diagenesis. Swiss grainstones had $\sim 6$ vol $\%$ porosity prior to burial, but some grainstones in Germany have higher values of mouldic porosity owing to their higher contents of ooids and aragonitic molluscs in shoal bodies and to telogenetic dissolution. 
Since it has been established that the early diagenetic processes in Switzerland acted on a regional scale, it can be assumed that the porosity of the Hauptmuschelkalk unit is $<6 \mathrm{vol} \%$ throughout the Swiss Molasse basin. Consequently, we conclude that the potential of the nondolomitized Upper Muschelkalk limestones for geothermal and gas storage applications in Switzerland is extremely low.

\section{Acknowledgements}

This study was conducted within the framework of Swiss National Science Foundation NRP 70 project 407040_153889 and Swiss Competence Center for Energy Research - Supply of Energy (SCCER-SoE). Drill cores were kindly provided by the National Cooperative for the Disposal of Radioactive Waste (Nagra) and by the Swiss Federal Railways (SBB). We thank Lukas Aschwanden for helpful discussions and for providing helium porosimetry measurements. This manuscript has been greatly improved by the comments and criticisms of Leslie A. Melim, an anonymous reviewer and Brian Jones, Editor in Chief of Sedimentary Geology.

\section{References}

Aigner, T. (1982). Calcareous tempestites: storm dominated stratification in Upper Muschelkalk Limestones (Middle Trias, SW Germany). In G. Einsele \& A. Seilacher (Eds.), Cyclic and Event Stratification (pp. 180-198). Berlin: Springer-Verlag.

Aigner, T. (1985). Storm depositional systems. Dynamic stratigraphy in modern and ancient shallow marine sequences. Berlin: Springer-Verlag.

Aigner, T., Hornung, J., Junghans, W.-D., \& Pöppelreiter, M. (1998). Baselevel cycles in the Triassic of the South-German Basin: a short progress report. Zentralblatt für Geologie und Paläontologie Teil. 1, 7-8, 537-544.

Al-Aasm, I.S., Taylor, B.E., \& South, B. (1990). Stable isotope analysis of multiple carbonate samples using selective acid extraction. Chemical Geology, 80, 119-125.

Al-Helal, A., Whitaker, F.F., \& Xiao, Y. (2012). Reactive transport modelling of brine reflux: dolomitization, anhydrite precipitation, and porosity evolution. Journal of Sedimentary Research, 82, 196-215.

Aller, R.C. (1982). Carbonate dissolution in nearshore terrigenous muds: the role of physical and biological reworking. Journal of Geology, 90, 79-95.

Bachmann, G.H. (1973). Die karbonatischen Bestandteile des Oberen Muschelkalkes (Mittlere Trias) in Südwest-Deutschland und ihre Diagenese. Arbeiten aus dem Institute für Geologie und Paläontologie die Universität Stuttgart, Neue Folge, 68, 1-99.

Berner, R.A. (1985). Sulphate reduction, organic matter decomposition and pyrite formation. Philosophical Transactions of the Royal Society of London A., 315, 25-38. 
Borkhataria, R., Aigner, T., Pöppelreiter, M.C., \& Pipping, J.C. (2005). Characterisation of epeiric "layer-cake" carbonate reservoirs: Upper Muschelkalk (Middle Triassic). The Netherlands. Journal of Petroleum Geology, 28, 14-42.

Bowen, G.J., \& Revenaugh, J. (2003). Interpolating the isotopic composition of modern meteoric precipitation. Water Resources Research, 39. https://doi.org/10.1029/2003WR002086.

Braun, S. (2003). Quantitative analysis of carbonate sandbodies: outcrop analog study from an epicontinental basin (Triassic, Germany) (Doctoral dissertation). University of Tübingen, Tübingen, Germany.

Brüderlin, M. (1971). Lithostratigraphische Profilserien durch den Oberen Muschelkalk im südwestlichen Baden-Württemberg. Jahresberichte und Mitteilungen des Oberrheinischen Geologischen Vereins., 53, 195-199.

Burchette, T.P., \& Wright, V.P. (1992). Carbonate ramp depositional systems. Sedimentary Geology, $79,3-57$.

Canfield D.E. (1993). Organic Matter Oxidation in Marine Sediments. In: R. Wollast, F.T. Mackenzie, \& L. Chou (Eds.), Interactions of C, N, P and S Biogeochemical Cycles and Global Change. NATO ASI Series (Series I: Global Environmental Change) 4 (pp. 333-363). Berlin: Springer-Verlag.

Chafetz, H.S., McIntosh, A.G., \& Rush, P.F. (1988). Freshwater phreatic diagenesis in the marine realm of recent Arabian Gulf carbonates. Journal of Sedimentary Petrology, 58, 433-440.

Cherns, L., \& Wright, V.P. (2000). Missing molluscs as evidence of large-scale, early skeletal aragonite dissolution in a Silurian sea. Geology, 28, 791-794.

Cherns, L., \& Wright, V.P. (2009). Quantifying the impacts of early diagenetic aragonite dissolution on the fossil record. PALAIOS, 24, 711-756.

Cherns, L., Wheeley, J.R., \& Wright, V.P. (2008). Taphonomic windows and molluscan preservation. Palaeogeography, Palaeoclimatology, Palaeoecology, 270, 220-229.

Chevalier, G., Diamond, L.W., \& Leu, W. (2010). Potential for deep geological sequestration of $\mathrm{CO}_{2}$ in Switzerland: a first appraisal. Swiss Journal of Geosciences, 103, 427-455.

Deutsche Stratigraphische Kommission (2002). Stratigraphische Tabelle von Deutschland 2002. Potsdam: Geoforschungs Zentrum.

Diamond, L.W., Aschwanden, L., Mazurek, M.,Wersin, P., Caldas, R., Adams, ... Madonna, C. (2013). Reservoir properties of the Upper Muschelkalk drill core at Schlattingen, NE Swiss Molasse Basin. A Combined Petrographic, Sedimentological, Geochemical and Petrophysical Study (Unpublished report). Bern: Institute of Geological Sciences.

Disler, C. (1914). Stratigraphischer Führer durch die geologischen Formationen im Gebiet zwischen Aare, Birs und Rhein. Basel: B. Wepf \& Co.

Emery, D., \& Marshall, J.D. (1989). Zoned calcite cements: has analysis outpaced interpretation? Sedimentary Geology, 65, 205-210.

Enos, P., \& Sawatsky, L.H. (1981). Pore networks in Holocene carbonate sediments. Journal of Sedimentary Petrology, 51, 961-985. 
Frank, J.R., Carpenter, A.B., \& Oglesby, T.W. (1982). Cathodoluminescence and composition of calcite cement in the Taum Sauk Limestone (Upper Cambrian), southeast Missouri. Journal of Sedimentary Petrology, 52, 631-638.

Franz, M., Henniger, M., \& Barnasch, J. (2013). The strong diachronous Muschelkalk/Keuper facies shift in the Central European Basin: implications from the type-section of the Erfurt Formation (Lower Keuper, Triassic) and basin-wide correlations. International Journal of Earth Sciences, 102, 761-780.

Franz, M., Kaiser, S.I., Fischer, J., Heunisch, C., Kustatscher, E., Luppold, F.W., Berner, U. \& Röhling, H.-G. (2015). Eustatic and climatic control on the Upper Muschelkalk Sea (late Anisian/Ladinian) in the Central European Basin. Global and Planetary Change, 135, 1-27.

Friedman, I., \& O'Neil, J.R. (1977). Compilation of stable isotope fractionation factors of geochemical interest. US Geological Survey Professional Paper 440.

Hardie, L.A. (1996). Secular variation in seawater chemistry: an explanation for the coupled secular variation in mineralogies of marine limestones and potash evaporites over the past 600 m.y. Geology, 24, 279-283.

Hendry, J.P., Ditchfield, P.W., \& Marshall, J.D. (1995). Two-stage neomorphism of Jurassic aragonitic bivalves: implications for early diagenesis. Journal of Sedimentary Research, 65, $214-224$.

Jones, G.D., \& Xiao, Y. (2005). Dolomitization, anhydrite cementation and porosity evolution in a reflux system: insights from reactive transport models. American Association of Petroleum Geologists Bulletin, 89, 577-601.

Jordan, P. (2016). Reorganisation of the Triassic stratigraphy in Northern Switzerland: overview and the new Dinkelberg, Kaiseraugst and Zeglingen formations. Swiss Journal of Geosciences, 109, 241-255.

Kaufmann, B., \& Wendt, J. (2000). Calcite cement successions in Middle Devonian (Givetian) carbonate mud buildups of the southern Ahnet Basin (Algerian Sahara). Carbonates and Evaporites, 15, 149-161.

Kim, S.-T., O'Neil, J.R., Hillaire-Marcel, C., \& Mucci, A. (2007). Oxygen isotope fractionation between synthetic aragonite and water: Influence of temperature and $\mathrm{Mg}^{2+}$ concentration. Geochimica et Cosmochimica Acta, 71, 4704-4715.

Knauth, L.P. (1979). A model for the origin of chert in limestone. Geology, 7, 274-277.

Knauth, L.P. (1994). Petrogenesis of chert. Reviews in Mineralogy and Geochemistry, 29, 233-258.

Koehrer, B.S., Heymann, C., Prousa, F., \& Aigner, T. (2010). Multiple-scale facies and reservoir quality variations within a dolomite body - outcrop analog study from the Middle Triassic, SW German Basin. Marine and Petroleum Geology, 27, 386-411.

Korte, C., Kozur, H.W., Bruckschen, P., \& Veizer, J. (2003). Strontium isotope evolution of Late Permian and Triassic seawater. Geochimica et Cosmochimica Acta, 67, 47-62.

Korte, C., Kozur, H.W., \& Veizer, J. (2005). $\delta^{13} \mathrm{C}$ and $\delta^{18} \mathrm{O}$ values of Triassic brachiopods and carbonate rocks as proxies for coeval seawater and palaeotemperature. Palaeogeography, Palaeoclimatology, Palaeoecology, 226, 287-306. 
Lasemi, Z., \& Sandberg, P.A. (1984). Transformation of aragonite-dominated lime muds to microcrystalline limestones. Geology, 12, 420-423.

Lohmann, K.C., \& Meyers, W.J. (1977). Microdolomite inclusions in cloudy prismatic calcites: a proposed criterion for former high-magnesium calcites. Journal of Sedimentary Research, 47, $1078-1088$

Machel, H.G. (2004). Concepts and models of dolomitization: a critical reappraisal. In: C.J.R. Braithwaite, G. Rizzi, \& G. Darke (Eds.), The Geometry and Petrogenesis of Dolomite Hydrocarbon Reservoirs 235 (pp. 7-63). London: Geological Society of London Special Publication.

Manning-Berg, \& A.R., Kah, L.C. (2017). Proterozoic microbial mats and their constraints on environments of silicification. Geobiology. https://doi.org/10.1111/gbi.12238.

Matter, A., Douglas, R.G., \& Perch-Nielsen, K. (1975). Fossil preservation, geochemistry, and diagenesis, of pelagic carbonates from Shatsky Rise, Northwest Pacific. Initial Reports of the Deep Sea Drilling Project, 32, 891-921.

Mazurek, M., Hurford, A.J., \& Leu, W. (2006). Unravelling the multi-stage burial history of the Swiss Molasse Basin: integration of apatite fission track, vitrinite reflectance and biomarker isomerisation analysis. Basin Research, 18, 27-50.

Melim, L.A., Swart, P.K., \& Maliva, R.G., (1995). Meteoric-like fabrics forming in marine waters: Implications for the use of petrography to identify diagenetic environments. Geology, 23, $755-758$.

Melim, L.A., Swart, P.K., \& Maliva, R.G. (2001). Meteoric and marine-burial diagenesis in the subsurface of Great Bahama Bank. In: R.N. Ginsberg (Ed.), Subsurface Geology of a Prograding Carbonate Platform margin, Great Bahama Bank: Results of the Bahamas Drilling Project (pp. 137-161). Society for Sedimentary Geology Special Publication 70.

Melim, L.A., Swart, P.K., \& Eberli, G.P. (2004). Mixing-zone diagenesis in the subsurface of Florida and the Bahamas. Journal of Sedimentary Research, 74, 904-913.

Merki, P. (1961). Der obere Muschelkalk im östlichen Schweizer Jura. Eclogae Geologicae Helvetiae, $54,137-220$.

Munnecke, A., Westphal, H., Reijmer, J.J.G., \& Samtleben, C. (1997). Microspar development during early marine burial diagenesis: a comparison of Pliocene carbonates from the Bahamas with Silurian limestones from Gotland (Sweden). Sedimentology, 44, 877-990.

Mutti, M., \& Weissert, H. (1995). Triassic monsoonal climate and its signature in Ladinian- Carnian carbonate platforms (Southern Alps, Italy). Journal of Sedimentary Research, 65, 357-367.

Noble, J.P.A., \& Van Stempvoort, D.R. (1989). Early burial quartz authigenesis in Silurian platform carbonates, New Brunswick, Canada. Journal of Sedimentary Petrology, 59, 65-76.

Palermo, D., Aigner, T., Seyfang, B., \& Nardon, S. (2012). Reservoir properties and petrophysical modelling of carbonate sand bodies: outcrop analogue study in an epicontinental basin (Triassic, Germany). In: J. Garland, J.E. Neilson, S.E. Laubach, \& K.J. Whidden (Eds.), Advances in Carbonate Exploration and Reservoir Analysis 370 (pp. 111-138). London: Geological Society of London Special Publications.

Parrish, J.T. (1993). Climate of the supercontinent Pangea. The Journal of Geology, 101, 215-233. 
Pearson Jr., F.J., Balderer, W., Loosli, H.H., Lehmann, B.E., Matter, A., Peters, T., Schmassmann, H., \& Gautschi, A. (1991). Applied Isotope Hydrogeology - A Case Study in Northern Switzerland. Amsterdam: Elsevier Scientific Publishers.

Pietsch, J.S., Wetzel, A., \& Jordan, P. (2016). A new lithostratigraphic scheme for the Schinznach Formation (upper part of the Muschelkalk Group of northern Switzerland). Swiss Journal of Geosciences, 109, 285-307.

Pöppelreiter, M., \& Aigner, T. (2008). High-resolution sequence stratigraphy, facies patterns and controls in a mixed epeiric shelf: implications for reservoir prediction (Lower Keuper, Triassic, German Basin). In: B.R. Pratt, \& C. Holmden (Eds.), Dynamics of Epeiric Seas. Geological Association of Canada Special Paper 48 (pp. 283-301). St. John's: Geological Association of Canada.

Preto, N., Spötl, C., \& Guaiumi, C., (2009). Evaluation of bulk carbonate $\delta^{13} \mathrm{C}$ data from Triassic hemipelagites and the initial composition of carbonate mud. Sedimentology, 56, 1329-1345.

Rahimpour-Bonab, H., Esrafili-Dizaji, B., \& Tavakoli, V. (2010). Dolomitization and anhydrite precipitation in Permo-Triassic carbonates at the South Pars gasfield, offshore Iran: controls on reservoir quality. Journal of Petroleum Geology, 33, 43-66.

Ramseyer, K., Fischer, J., Matter, A., Eberhardt, P., \& Geiss, J. (1989). A cathodoluminescence microscope for low intensity luminescence. Journal of Sedimentary Research, 59, 619-622.

Ramseyer, K., Miano, T.M., D'Orazio, V.,Wildberger, A.,Wagner, T., \& Geister, J. (1997). Nature and origin of organic matter in carbonates from speleothems, marine cements and coral sediments. Organic Geochemistry, 26, 361-378.

Reinhold, C. (1999). Dog-tooth cements: indicators of different diagenetic environments. Zentralblatt für Geologie und Paläontologie Teil I, v. 1997, 1221-1235.

Rozanski, K., Araguás- Araguás, L., \& Gonfiantini, R. (1993). Isotopic patterns in modern global precipitation. In: P.K. Swart, K.C. Lohmann, J. McKenzie, \& S. Savin (Eds.), Climate Change in Continental Isotopic Records. Geophysical Monography 78 (pp. 1-36). Washington: American Geophysical Union.

Ruf, M., \& Aigner, T. (2004). Facies and poroperm characteristics of a carbonate shoal (Muschelkalk, South German Basin): a reservoir analogue investigation. Journal of Petroleum Geology, 27, 215-239.

Ruppel, S.C., \& Cander, H.S. (1988). Dolomitization of Shallow-water Platform Carbonates by Seawater and Seawater-derived Brines: San Andres Formation (Guadalupian), West Texas. Society of Economic Paleontologists and Mineralogists Special Publication, 43, 245-262.

Schauer, M., \& Aigner, T. (1997). Cycle stacking pattern, diagenesis and reservoir geology of peritidal dolostones, Trigonodus-Dolomite, Upper Muschelkalk (Middle Triassic, SWGermany). Facies, 37, 99-114.

Schmoker, J.W., \& Hester, T.C. (1986). Porosity of the Miami limestone (Late Pleistocene), Lower Florida Keys. Journal of Sedimentary Petrology, 56, 629-634.

Sheppard, C., Al-Husiani, M., Al-Jamali, F., Al-Yamani, F., Baldwin, R., Bishop, ... Zainal, K. (2010). The Gulf: a young sea in decline. Marine Pollution Bulletin, 60, 13-38. 
Smart, P.L., Dawans, J.M., \& Whitaker, F. (1988). Carbonate dissolution in a modern mixing zone. Nature, 335, 811-813.

Stampfli, G.M., \& Borel, G.D. (2002). A plate tectonic model for the Paleozoic and Mesozoic constrained by dynamic plate boundaries and restored synthetic oceanic isochrones. Earth and Planetary Science Letters, 196, 17-33.

Szulc, J. (2000). Middle Triassic evolution of the northern Peri-Tethys as influenced by early opening of the Tethys. Annales Societatis Geologorum Poloniae, 70, 1-48.

Tobin, K.J., \& Walker, K.R. (1994). Meteoric diagenesis below a submerged platform: implications for $\delta^{13} \mathrm{C}$ compositions prior to pre-vascular plant evolution, Middle Ordovician, Alabama, U.S.A. Sedimentary Geology, 90, 95-111.

Török, Á. (2000). Formation of dolomite mottling in Middle Triassic ramp carbonates (Southern Hungary). Sedimentary Geology, 131, 131-145.

Tucker, M., \& Marshall, J. (2004). Diagenesis and geochemistry of Upper Muschelkalk (Triassic) buildups and associated facies in Catalonia (NE Spain): a paper dedicated to Francesc Calvet. Geologica Acta, 2, 257-269.

Tucker, M.E., \& Wright, V.P. (1990). Carbonate Sedimentology. Oxford: Blackwell Scientific Publications.

Walker, K.R., Jernigan, D.G., \& Weber, L.J. (1990). Petrographic criteria for the recognition of marine, syntaxial overgrowths, and their distribution in geologic time. Carbonates and Evaporites, 5, 141-151.

Walter, L.M., Bischof, S.A., Patterson, W.P., \& Lyons, T.W. (1993). Dissolution and Recrystallization in Modern Shelf Carbonates: Evidence From Pore Water and Solid Phase Chemistry. Philosophical Transactions of the Royal Society, 334, 27-36.

Ward, W.C., \& Halley, R.B. (1985). Dolomitization in a mixing zone of near-seawater composition, Late Pleistocene, northeastern Yucatán Peninsula. Journal of Sedimentary Petrology, 55, $407-420$.

Wood, W.W., Sanford, W.E., \& Frape, S.K. (2005). Chemical openness and potential for misinterpretation of the solute environment of coastal sabkhat. Chemical Geology, 215, 361372.

Zeeh, S., \& Geng, A. (2001). Origin and diagenesis of dolomite from the Muschelkalk group (Middle Triassic) of SW Germany. Neues Jahrbuch für Geologie und Paläontologie Abhandlungen, 221, 359-395.

Ziegler, P.A. (1990). Geological Atlas of Western and Central Europe. 2nd edn. The Hague: Shell Internationale Petroleum Maatschappij. 